Review

\title{
Oxy-Steam Reforming of Natural Gas on Ni Catalysts-A Minireview
}

\author{
Magdalena Mosinska, Malgorzata I. Szynkowska ${ }^{(D)}$ and Pawel Mierczynski *(D) \\ Faculty of Chemistry, Institute of General and Ecological Chemistry, Lodz University of Technology, \\ Zeromskiego 116, 90-924 Lodz, Poland; magdalena.mosinska@dokt.p.lodz.pl (M.M.); \\ malgorzata.szynkowska@p.lodz.pl (M.I.S.) \\ * Correspondence: pawel.mierczynski@p.lodz.pl; Tel.: +48-42-631-31-25
}

Received: 24 June 2020; Accepted: 4 August 2020; Published: 7 August 2020 updates

\begin{abstract}
Nowadays, the reforming of natural gas is the most common of hydrogen or syngas generation process. Each reforming process leads to the achievement of specific goals and benefits related to investment costs. The disadvantage of the reforming process is the need to preclean it mostly from the sulfur and nitrogen compounds. The solution to this problem may be liquefied natural gas (LNG). Liquefied natural gas has recently been seen as an energy source and may be a promising replacement for natural gas. The constant development of the pipeline network, safe transport and a lot of advantages of LNG were contributed to the research development related to the usage of LNG in energy generation technologies. The presented review is a literature discussion on the processing of methane used to produce hydrogen with particular emphasis on the processes of oxy-steam reforming of natural or liquefied natural gas (OSR-LNG). In addition, a key consideration in this article includes $\mathrm{Ni}$ catalyst systems used in the oxy-steam reforming of methane or LNG reactions. An analysis of the OSR process conditions, the type of catalyst and the OSR of the methane reaction mechanism may contribute to the development of a modern, cheap catalyst system, which is characterized by high activity and stability in the oxy-steam reforming of natural gas or LNG (OSR-LNG).
\end{abstract}

Keywords: hydrogen production; oxy-steam reforming; liquefied natural gas; LNG; catalysts

\section{Introduction and Scope of Review}

The current level of civilization development and greater access to information have increased awareness of the dangers of environmental pollution and the greenhouse effect. One of the greatest threats to the earth and people are traditional fossil fuels, the combustion of which releases large amounts of harmful gases into the environment, such as carbon dioxide, nitrous oxide, sulphur oxide, carbon monoxide and hydrocarbons. More and more countries are slowly giving up energy produced from fossil fuels. In addition, the increasing restrictions on the emission limits of harmful gases and the continued exploitation of non-renewable energy sources result in continuous research into the development of a new, efficient and environmentally friendly energy source. The usage of alternative energy sources reduces the consumption of fossil fuels and increases the energy autonomy. Therefore, the important subject of today's scientists research is focused on developing a new energy generation technology's. One of the widely discussed topics is the production of hydrogen and its use as an energy carrier [1]. Hydrogen as a fuel has many advantages. It is the lightest of all gases and has the lowest density compared to other substances. The combustion of hydrogen is a highly explosive and exothermic process. In addition, hydrogen has a high self-ignition temperature and low ignition initiation energy, which improves its combustion. Its combustion produces heat and water vapor. The energy value of hydrogen is very high and equal $120 \mathrm{MJ} / \mathrm{kg}$ (the energy value of coal and gasoline equal is 25 and $47 \mathrm{MJ} / \mathrm{kg}$, respectively). The specific heat of hydrogen expressed per mass unit is the 
very high, which contributes to its easy storage [2]. Hydrogen has been used in energy production and fuel cell technology [3-18]. Currently, fuel cells are the most promising device for energy and heat generation. The most popular catalytic materials used in fuel cells are platinum, their alloy and transition metal oxides catalysts. A typical fuel cell consist of electrodes: anode and cathode which conduct electrons and electrolyte as an ions conductor (see Figure 1).

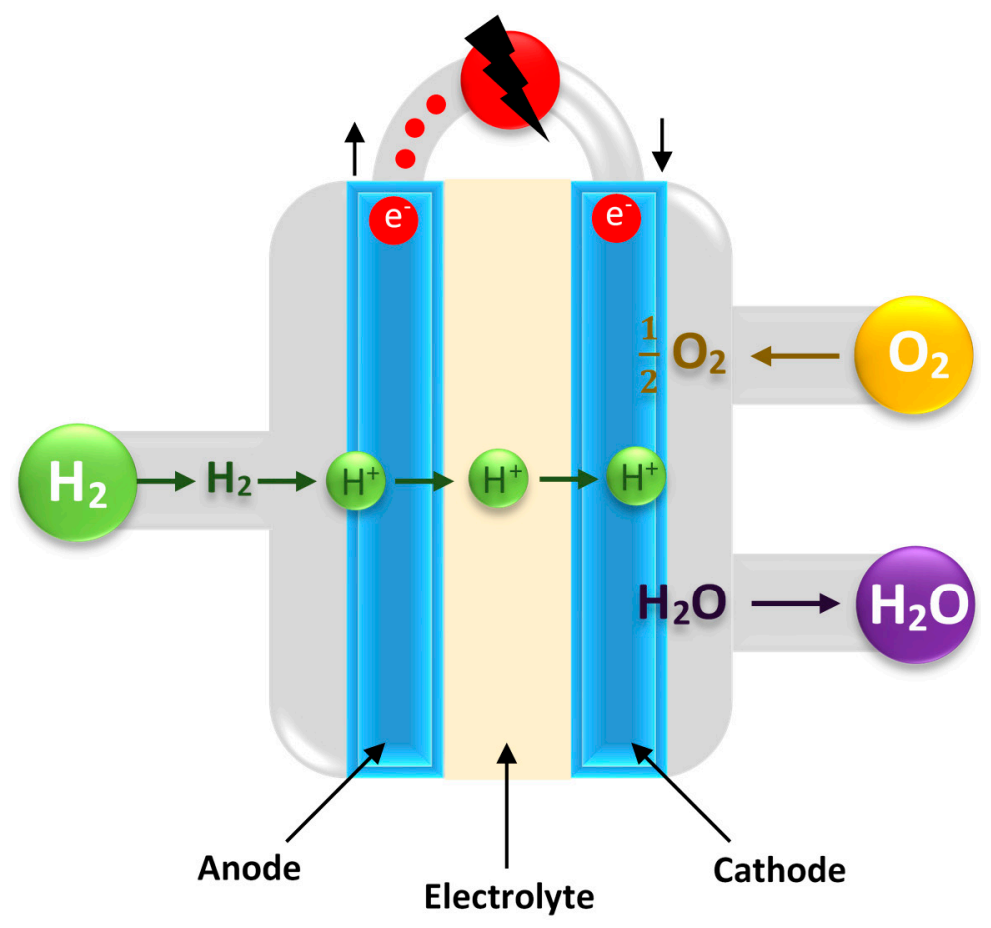

Figure 1. The construction and operation of a fuel cell.

Hydrogen is fed to the anode and oxygen to the cathode. Molecular hydrogen is decomposed into a proton and an electron at the anode. The electrons are delivered to the cathode by an external circuit, which generates electricity. On the other hand, the electrolyte is involved in the transport of the proton to the cathode. Water production takes place at the cathode. Fuel cells can be also be powered by liquid or gas hydrocarbons. The base source of hydrogen on the Earth is syngas, which can be produce by the reforming of natural gas. The continuing trend shows that natural gas remains the primary fuel for the high power stationary fuel cells and is also common in small and medium power domestic fuel cells [19]. Currently, the main technology of hydrogen production is based on steam reforming of methane [20,21]. The technology of receiving hydrogen from natural gas in the first stage involves the conversion of organic sulphur compounds and olefins to hydrogen sulphide and hydrocarbons and removal of hydrogen sulphide. The second stage involves proper steam reforming of methane and higher hydrocarbons and the conversion of carbon monoxide with water vapour. These conditions make, that from the technological point of view the production of hydrogen via reforming of natural gas is difficult, because this process requires the purification of natural gas from the sulphur and nitrogen compounds. During the process of liquefying, natural gas is cleaned, mainly from water and carbon dioxide in order to prevent the formation of solid particles when the gas is cooled to a temperature of about $-160{ }^{\circ} \mathrm{C}$ (see Figure 2) [22]. As a result, LNG is a very clean gas which composed in $95 \%$ from methane and only $5 \%$ are other components [23]. After the condensation process, pure, odourless and colourless fuel is produced. LNG is about 600 times smaller in volume than in the gas phase. This makes LNG more economical to transport and store. However, the structure of the methane molecule make the methane reforming process challenging due to the fact of high energy required to dissociate the $\mathrm{C}-\mathrm{H}$ bond, which is $435 \mathrm{~kJ} / \mathrm{mol}$. This fact indicated that reforming of methane required high reaction temperature in order to achieve high conversion of hydrogen components. 
The boiling point of LNG is from -166 to $-157^{\circ} \mathrm{C}$ at atmospheric pressure and the LNG density is from $430-470 \mathrm{~kg} / \mathrm{m}^{3}$ [24]. These facts indicate that LNG can be economically and safely transported by ships or trucks to the destination places, where it can be used in many industry branches [25-27]. The use of liquefied natural gas favours the development of LNG transport capacity and above all fleet expansion, and the high price competitiveness of LNG compared to gas transported via pipelines. LNG can be a source of hydrogen [28-30] to power fuel cells for generating electricity and/or heat at the destination [31-33]. Interest of the reforming of LNG is mainly due to its potential application in fuel cells technology [34]. Fuel cells technology is one of the possible application which can be used to replace fossil fuels. An example of one well-known technology is fuel cell with a polymer proton-exchange membrane (PEMFC). PEMFC can certainly be used to power cars, achieving much better fuel utilization rates, compared to an engine with a low content of toxic substances in the exhaust gas. The exhaust gases produced during the combustion process of fossil fuel are responsible for climate change and global warming. This problem does not occur in the case of fuel cells. Currently, the profitability of an FCV (Fuel Cell Vehicle) is compared to that of modern hybrids. Therefore, it is important to develop a new/cheaper alternative to fossil fuel technology, which allow us to generate energy at the place where we needed it. Additionally, it is worth emphasizing that the current modern generators using together with the system powered by hydrogen produced using fuel cell technology, are very quiet, efficient and produce a minimum amount of pollution. Such application is possible due to the short start-up time of fuel cells and high quality of supplied electricity. Another advantage of using LNG as a hydrogen source is the ability to receive liquefied natural gas from marginal or waste methane sources with relatively low methane content (e.g., mines, landfill, with cattle farms), which will benefit the environment by reducing emissions to the atmosphere.

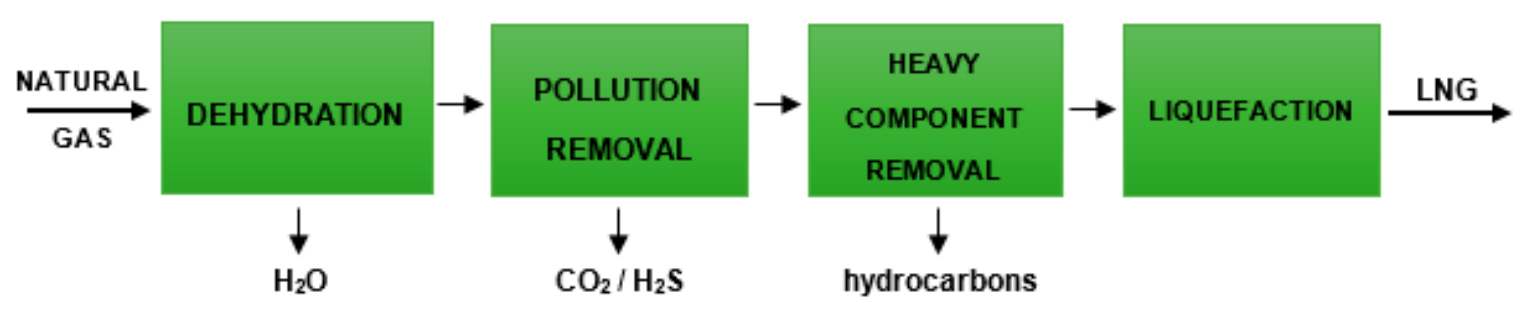

Figure 2. Liquefied natural gas (LNG) production process.

\section{Possible Routes for Hydrogen Production via Processing of Methane}

Nowadays industrial production of hydrogen is based on steam reforming of natural gas to synthesis gas. Typically, catalytic reforming of natural gas is carried out at temperatures of $750-900{ }^{\circ} \mathrm{C}$ and under a pressure of $34 \mathrm{MPa}$. Obtained synthesis gas has high volume ratio of $\mathrm{H}_{2}$ : $\mathrm{CO}$ (about 3:1). The main component of natural gas is methane, and other components such as ethane, propane and heavier hydrocarbons, nitrogen, oxygen, carbon dioxide, sulphur. The composition of the natural gas necessitates the pre-cleaning prior to further processing. Raw natural gas requires denitrification and desulfurization, and then the purified gas can be later used for hydrogen production in one act. An alternative technology to energy production is based on liquefied natural gas (LNG -, Liquefied Natural Gas") [35]. LNG infrastructure in modern cities may become more widespread in the future, which will make LNG well suited as a hydrogen source for residential reformers in fuel cell applications. There are three methods of methane processing. It should be emphasized, that several variants of the reforming of natural gas processes can be distinguished, viz: steam (SR), dry (DR) and oxy steam (OSR) reforming [36-40]. In each of these processes, the most important step is the initial purification of natural gas from sulphur and nitrogen compounds to make its useful for hydrogen production [41,42]. In Tables 1 and 2 we present the reaction schemes of methane reforming and other reaction equations accompanying of natural gas processing. In the steam reforming of methane (SRM) process, methane react with steam on catalyst bed produces syngas $\left(\mathrm{CO}\right.$ and $\left.\mathrm{H}_{2}\right)$. SRM is a very energy consuming process due to the high endothermic nature of this reaction (1) [43]. The SRM process 
require the supply a lot of heat and its usually carried out at high temperature above $750{ }^{\circ} \mathrm{C}$ and under 3-25 bar pressure [19,44]. In steam reforming of methane reaction a syngas with the highest ratio of $\mathrm{H}_{2} / \mathrm{CO}$ equal to or almost equal to 3 [44-48]. The main reaction running in parallel with the SRM process is the water gas shift reaction (WGS) which lead to $\mathrm{CO}_{2}$ production (2). The high temperature of SRM process favours carbon deposits formation during methane decomposition (7) and Boudouard (8) reactions, respectively. The low SRM reaction rate confirmed that the usage of this process in fuel cell technology in mobile application is rather complicated. Nevertheless, methane steam reforming is the dominant industry process used to syngas production which can be apply to hydrogen generation for fuel cells stationary system application. The high reaction temperature of SRM process makes the reaction expensive from an economic point of view. The present studies focus on an alternative way of syngas production which will be more economic viability and fill the established purposes on this type of energy generation technology. Therefore, more attention is focused on the other types of methane reforming processes such as: partial oxidation (POM) [49-53], dry reforming (DR) [54-61] and oxy - steam reforming (OSR), respectively. The partial oxidation of methane (POM) process (3) leads to syngas production with $\mathrm{H}_{2}$ to $\mathrm{CO}$ ratio equal 2. The POM reaction runs 10-100 times faster than SRM, which allows the use of a small reactors in partial oxidation process $[62,63]$. Therefore, the POM [64-66] reaction is suitable process for the syngas production with low investment and usage of a simple equipment $[67,68]$. However, the partial oxidation of methane process has many limits which generate several problems. POM reaction may be associated with a risk of explosion, hot spot formation on the catalyst surface and as a result a lower value $\mathrm{H}_{2} / \mathrm{CO}$ ratio can be obtained or may lead to catalyst deactivation $[69,70]$. Dry reforming of methane (DRM) process use $\mathrm{CO}_{2}$ which is the most abundant global greenhouse gas (GHG) in order to decomposed of methane (4). In this process the syngas is produced with a relative low $\mathrm{H}_{2} / \mathrm{CO}$ ratio equal 1 which suit to applied in Fisher - Tropsch process to hydrocarbons production on iron catalysts [71-83]. Carbon dioxide consumption in DRM process has a positive effects on environment and limit the GHG emission [84]. Typically DRM process is performed in temperature range $600-1000{ }^{\circ} \mathrm{C}$ and at low pressure. In comparison to autothermal and steam reforming, the dry reforming of methane is the most endothermically reaction what caused that $\mathrm{CO}_{2}$ oxidizing agent is the most stable compared to the steam and oxygen used in autothermal and steam reforming of methane processes. However, the dry reforming of methane process showed to be unpractical industrially due to fact of fast possibility of catalyst deactivation, requirement of pure $\mathrm{CO}_{2}$ used and long-time of DRM process [85-88]. In general, the oxy - steam reforming (OSR) of methane reaction is the combination of the oxidation $(3,5)$ and steam reforming $(1,2)$ of methane processes. Thermodynamically, the OSR of methane reaction is a connection of endothermic and exothermic processes what allow to perform this process automatically without need to supply any external heat. Therefore, the oxy - steam reforming (OSR) of methane can be an attractive alternative to steam and partial oxidation of methane. Conduction of OSR process allow to avoid the danger of an explosion in POM reaction, reduce additional steam costs in SRM process. It also allow reduce start-up time and control the produced $\mathrm{H}_{2} / \mathrm{CO}$ ratio by changing the composition of the steam, oxygen and methane. OSR of methane reaction provide to achieve higher values of $\mathrm{CH}_{4}$ conversion and $\mathrm{H}_{2}$ yield due to combination of POM and SRM reactions in one act [89]. The efficiency of CO formation is lower in OSR of methane process, because of $\mathrm{CO}$ can be oxidized to carbon dioxide. The value of hydrogen formation is in the range of values that can be obtained for SRM and POM processes $[69,90]$. The autothermal nature of the OSR of methane reaction prevents catalyst deactivation by sintering or carbon deposit formation. During OSR reaction, syngas is generated as a result of an advanced production process at a low cost and using compact equipment. Hydrogen produced via reforming of methane processes is used in various areas of the chemical industry for example in the methanol synthesis [77,91-97], ammonia and other chemicals production [98-105]. Nevertheless, today's scientists focus on hydrogen which can be use in fuel cells. In order to obtain pure hydrogen, the obtained syngas is further processed in order to purify it of sulphur, $\mathrm{CO}_{2}$ and $\mathrm{CO}$ compounds. The presented methods are ones of the most commonly used for syngas and hydrogen generation [106]. 
Table 1. Description of the different types of methane reforming processes.

\begin{tabular}{cccc}
\hline Process & Reaction Equation & $\mathbf{H}_{2} / \mathrm{CO}$ Ratio & $\Delta \mathbf{H}(\mathbf{k J} / \mathbf{m o l})$ \\
\hline Steam reforming (SR) & $\begin{array}{c}\text { (1) } \mathrm{CH}_{4}+\mathbf{H}_{2} \mathbf{O} \rightarrow \mathbf{C O}+3 \mathbf{H}_{2} \\
\text { (2) } \mathbf{C O}+\mathbf{H}_{2} \mathbf{O} \rightarrow \mathbf{C O}_{2}+\mathbf{H}_{2}\end{array}$ & $\geq 3$ & 206 \\
& (3) $\mathrm{CH}_{4}+\frac{1}{2} \mathbf{O}_{2} \rightarrow \mathbf{C O}+2 \mathbf{H}_{2}$ & 2 & -41 \\
\hline Partial oxidation (POM) & (4) $\mathrm{CH}_{4}+\mathrm{CO}_{2} \rightarrow 2 \mathbf{C O}+2 \mathbf{H}_{2}$ & 1 & 247 \\
\hline Dry reforming (DR) & (1) $\mathrm{CH}_{4}+\mathbf{H}_{2} \mathbf{O} \rightarrow \mathbf{C O}+3 \mathbf{H}_{2}$ & It depends & 206 \\
Oxy-steam reforming (OSR) & $\begin{array}{c}\text { (2) } \mathbf{C O}+\mathbf{H}_{2} \mathbf{O} \rightarrow \mathbf{C O} \mathbf{O}_{2}+\mathbf{H}_{2} \\
\text { (3) } \mathrm{CH}_{4}+\frac{1}{2} \mathbf{O}_{2} \rightarrow \mathbf{C O}+2 \mathbf{H}_{2}\end{array}$ & $\begin{array}{c}\text { on the reaction } \\
\text { mixture composition }\end{array}$ & -41 \\
& (5) $\mathrm{CH}_{4}+2 \mathbf{O}_{2} \rightarrow \mathbf{C O}_{2}+2 \mathbf{H}_{2} \mathbf{O}$ & -880 \\
\hline
\end{tabular}

Table 2. Reactions accompanying the methane reforming processes.

\begin{tabular}{|c|c|c|}
\hline Process & Reaction Equation & $\Delta \mathrm{H}(\mathrm{kJ} / \mathrm{mol})$ \\
\hline $\begin{array}{c}\text { Water gas shift (WGS) } \\
\text { Reverse water gas shift (RWGS) }\end{array}$ & $\begin{array}{l}\text { (2) } \mathrm{CO}+\mathrm{H}_{2} \mathrm{O} \rightarrow \mathrm{CO}_{2}+\mathrm{H}_{2} \\
\text { (6) } \mathrm{CO}_{2}+\mathrm{H}_{2} \rightarrow \mathrm{CO}+\mathrm{H}_{2} \mathrm{O}\end{array}$ & $\begin{array}{c}-41 \\
41\end{array}$ \\
\hline Carbon deposit formation & $\begin{array}{c}\text { (7) } \mathrm{CH}_{4} \rightarrow \mathrm{C}+2 \mathrm{H}_{2} \\
\text { (8) } 2 \mathrm{CO} \rightarrow \mathrm{C}+\mathrm{CO}_{2} \\
\text { (9) } \mathrm{CO}+\mathrm{H}_{2} \rightarrow \mathrm{C}+\mathrm{H}_{2} \mathrm{O}\end{array}$ & $\begin{array}{l}+75 \\
-172 \\
-131\end{array}$ \\
\hline Coal gasification & $\begin{array}{c}\text { (10) } \mathrm{C}+\mathrm{H}_{2} \mathrm{O} \rightarrow \mathrm{CO}+\mathrm{H}_{2} \\
\text { (11) } \mathrm{C}+\mathrm{O}_{2} \rightarrow \mathrm{CO}_{2} \\
\text { (12) } \mathrm{C}+\frac{1}{2} \mathrm{O}_{2} \rightarrow \mathrm{CO} \\
\text { (13) } \mathrm{C}+\mathrm{CO}_{2} \rightarrow 2 \mathrm{CO}\end{array}$ & $\begin{array}{c}131 \\
-395 \\
-110 \\
172\end{array}$ \\
\hline Methanation & $\begin{array}{l}\text { (14) } \mathrm{CO}+3 \mathrm{H}_{2} \rightarrow \mathrm{CH}_{4}+\mathrm{H}_{2} \mathrm{O} \\
\text { (15) } 2 \mathrm{CO}+2 \mathrm{H}_{2} \rightarrow \mathrm{CH}_{4}+\mathrm{CO}_{2}\end{array}$ & $\begin{array}{l}-206 \\
-247\end{array}$ \\
\hline
\end{tabular}

Generally, the methane reforming is crucial process in the world energetic economy. Independently of the reforming type, methane reforming is the first step of natural gas processing to precious energetic components which finally lead to produce high pure hydrogen. However, the type of methane reforming has an influence on the obtained $\mathrm{H}_{2} / \mathrm{CO}$ ratio. It is well know that steam reforming of methane (SRM) reaction leads to produce syngas with the highest $\mathrm{H}_{2} / \mathrm{CO}$ ratio equal or above 3 . When the steam will be replace by $\mathrm{CO}_{2}$ (dry reforming of methane) the produced $\mathrm{H}_{2}$ to $\mathrm{CO}$ ratio is equal 1. The SRM and DRM process are strong endothermic reactions (see Figure 3) which leads to increasing the reaction mixture volume and thereby reaction pressure. The thermodynamic condition of these two reactions suggests the used of high temperature and low pressure moves the reaction equilibrium toward products. However, the used of low pressure is not economic favourable because of the need to compress to for further planned processes. The use of high reaction temperature in order to obtain required amount of heat cause the negative energetic balance. In partial oxidation of methane reaction the ratio of $\mathrm{H}_{2} / \mathrm{CO}$ equal about 2 and the reaction heat is low which seem to be optimal solution. However, during the POM reaction take place reforming of methane and WGS processes which lead to obtain products dependent to reaction equilibrium. The autothermal reforming of methane which is also name the oxy - steam reforming of methane (OSR of methane) is a combination of the two process: partial oxidation (POM) and steam reforming (SR). This connection is advantageous because combine the exothermic POM reaction with endothermic SR process which allow to perform the oxy - steam reforming of methane without having to provide huge amounts of heat. The steam addition to the mixture of partial oxidation of methane limits carbon deposit formation during SRM process. The OSR of methane reaction is designed to save energy and produce syngas with high ratio of $\mathrm{H}_{2}$ to $\mathrm{CO}$. Finally, the choice of the most proper type of methane reforming process for further purpose will be depend on profitability of the investment and its further usage. The cost-effectiveness of this technology also depends on the methane delivery infrastructure and natural gas prices. It is worth highlights that the 
effectiveness of syngas production are also essentially determined by catalytic materials used in this process [107]. The effectiveness of OSR of methane process strongly depends on the reaction conditions such as: temperature, pressure and substrate concentration in reactor which determine the kinetics of this process. Haynes and Shekhawat [108] reported about the influence of the reaction conditions of OSR of methane process on the amount of the obtained products. They claimed that in OSR of methane reaction the $\mathrm{CH}_{4}$ conversion reached the noticeable values above $400{ }^{\circ} \mathrm{C}$ and increasing to about $100 \%$ at about $700{ }^{\circ} \mathrm{C}$. The $\mathrm{H}_{2}$ yield increase with increasing of the OSR of methane reaction temperature to about $750{ }^{\circ} \mathrm{C}$ but above this temperature the recorded hydrogen yield has started gradually decrease. In addition, above $750{ }^{\circ} \mathrm{C}$ the $\mathrm{H}_{2}$ to $\mathrm{CO}$ ratio between produced products also decrease because of the RWGS reaction is privileged at high temperature. The catalysts used in OSR process should be very active and selective in both steam and oxy-steam reforming processes. In addition, this material must be thermally stable in order to run the process at about $800{ }^{\circ} \mathrm{C}$ to achieve maximum $\mathrm{H}_{2}$ yields and avoid carbon formation. High thermal stability of the catalytic material is extremely important because of the fact that running process through long period leads to loss of active surface area as a result of sintering/agglomeration process. It is believed that the reforming catalysts should operate at gas hourly space velocities (GHSV) of $200,000 \mathrm{~h}^{-1}$ (calculated at $25^{\circ} \mathrm{C}$ and $0.1 \mathrm{MPa}$ ) reaching above $90 \%$ of fuel conversion, and $\mathrm{H}_{2}$ selectivity above $80 \%$ during $5000 \mathrm{~h}$ of catalyst operation. It is also worth emphasizing that during the oxy - steam reforming of methane reaction the increase of the volume of the reaction products is observed. Therefore, the lower pressures are prefer due to thermodynamic point of view. The authors reported also that increase of the reaction pressure caused decreased of the $\mathrm{H}_{2}$ and $\mathrm{CO}$ amount. However, the opposite trend we observed for $\mathrm{CH}_{4}$, and $\mathrm{H}_{2} \mathrm{O}$ concentration. No effect of process pressure on the $\mathrm{CO}_{2}$ amount formed during the OSR of methane was observed.

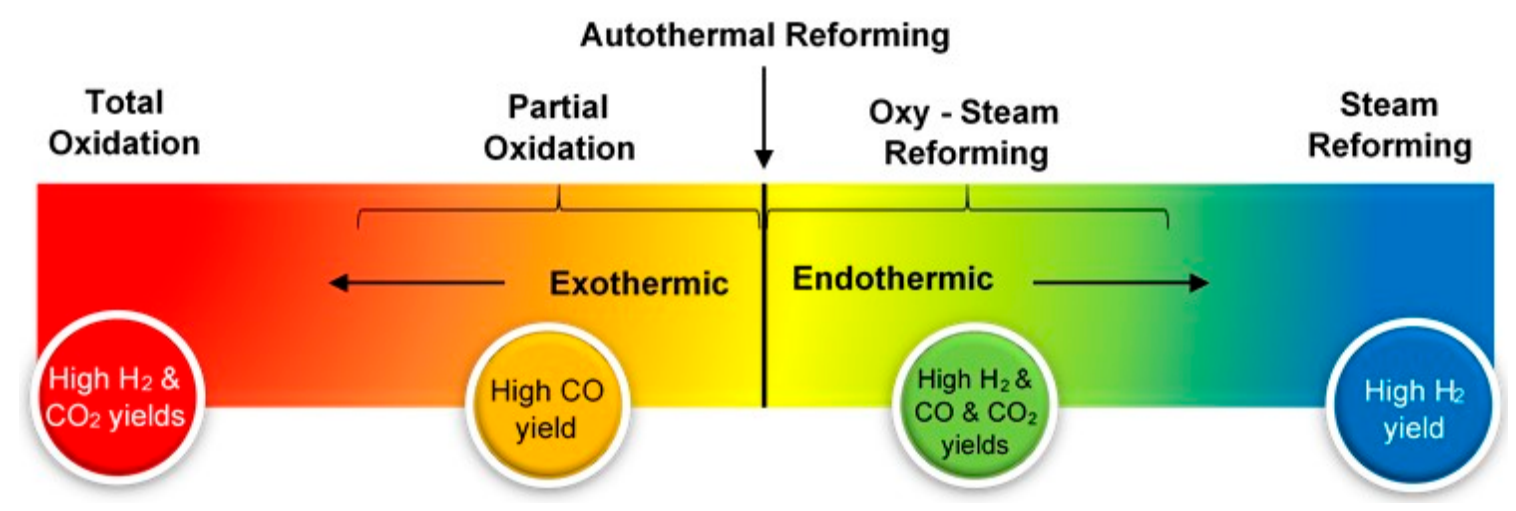

Figure 3. Illustration of a range of activities and conditions of methane processing $[108,109]$.

\section{Oxy-Steam Reforming of the Methane Reaction Mechanism}

Various reaction mechanisms and kinetic models have been proposed in the literature concerning reforming of methane processes. However, despite the effort to clarify these aspects, existing research data have not been fully explained. There is not commonly known the general mechanism of the oxy steam reforming of methane process which will be suit to all substrate and reaction conditions [110]. The OSR process mechanism depends on the used catalytic materials, reaction conditions and the type of starting material used in this process. In the literature, the oxy-steam reforming of aliphatic and aromatic hydrocarbons, the OSR reaction mechanism is described as a combination of two independent types of steam reforming and oxidation reaction mechanisms [108]. It is speculated in the literature that the OSR of hydrocarbons takes place in two stages [111-113]. In the first step, the hydrocarbon is burned using all available $\mathrm{O}_{2}$, resulting in the formation of $\mathrm{H}_{2}$ and $\mathrm{CO}_{2}$. The kinetic of the combustion process is very fast which causes the slight usage of the catalyst bed. The stoichiometry of this reaction show that only $25 \%$ of hydrocarbon fuel is converted in this step of OSR reaction. In the next stage of OSR process the rest of hydrocarbon fuel is reformed using steam and/or $\mathrm{CO}_{2}$. After the first combustion step in OSR process the endothermically reactions dominate. Additionally, the equilibrium 
between WGS and RWGS reaction has a crucial role in this step, because determine the selectivity of the obtaining products (see Figure 4) [108].

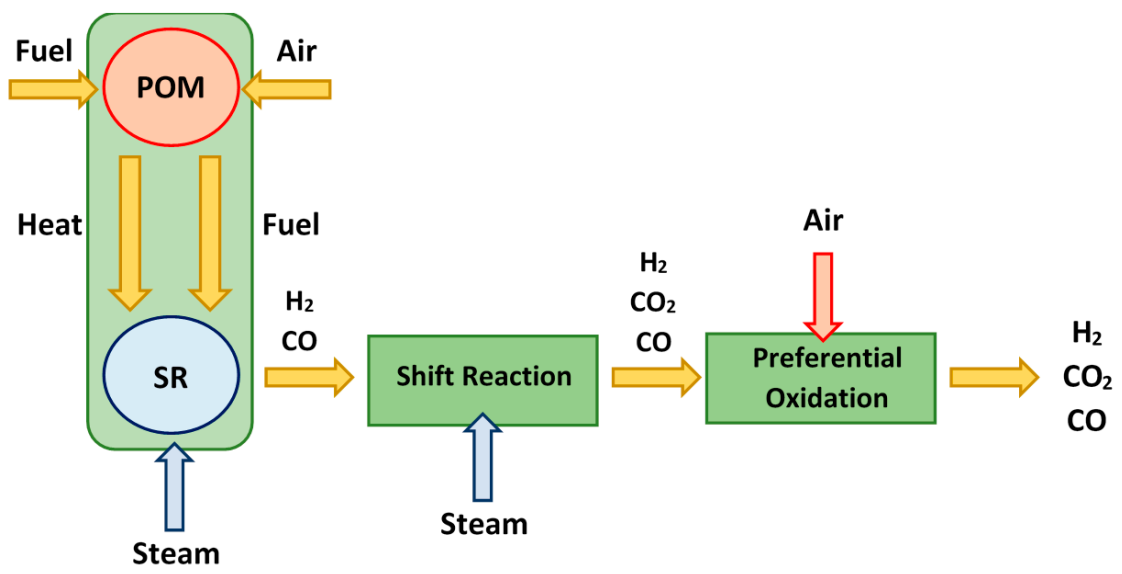

Figure 4. The autothermal reforming scheme.

In general, the combustion process is very fast and takes place at the inlet of the catalyst bed, resulting in a very high temperature in the combustion zone. Whereas, the steam reforming reaction performs over the catalyst bed and does not overlap with the combustion zone. This leads to a large temperature gradient across the catalyst bed (see Figure 5). The partial oxidation and steam reforming of methane processes were also performed in fluidized reactor which showed that heat transportation in this type of reactor is significant faster and hot spot formation is not observed. This indicates that the combination of POM and SRM reactions in one act can be more safety and stable to carried out in fluidized reactor [111].

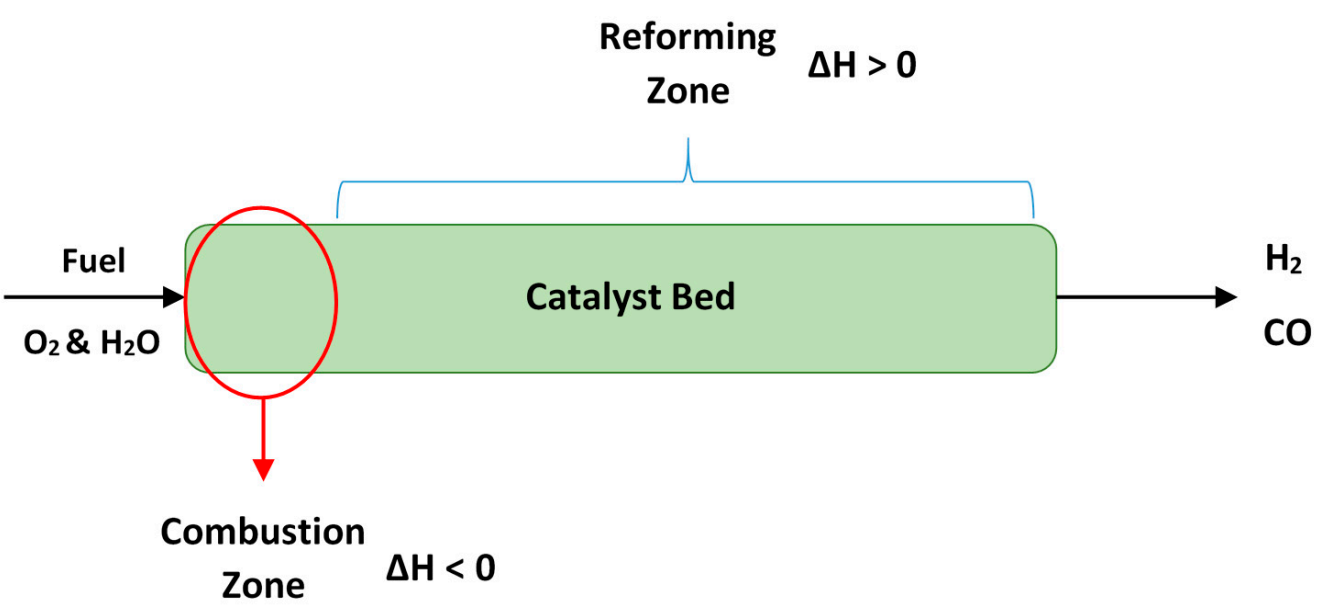

Figure 5. The combustion-reforming mechanism of the oxy-steam reforming (OSR) process: catalyst bed description.

Delgado et al. [110] reported about the reactions pathways taking place during oxidation and reforming of methane processes over nickel catalyst (see Figure 6). The experimental studies were performed in a flow reactor. The obtained experimental results and numerical studies allowed to design the kinetic model of oxidation and reforming of methane processes. Authors propose thermodynamically consistent surface reaction mechanism based on several sets of experiments performed for oxidation and reforming of methane processes. The proposed kinetic model involves adsorption and desorption steps of all reactants and products and the possible reactions steps are given in Figure 6. They confirmed that the availability of the adsorbed atomic oxygen $\mathrm{O}(\mathrm{s})$, produced as a result of dissociative adsorption of $\mathrm{O}_{2}, \mathrm{H}_{2} \mathrm{O}$ or $\mathrm{CO}_{2}$ plays crucial role in order to determine the reaction 
rate. The proposed by authors model can predict the product distribution used to feed POM and SR of methane reactions in order to syngas production. The experimental and numerical results confirmed that in the oxy - steam reforming of methane process in the first step the oxidation of methane take place and $\mathrm{H}_{2} \mathrm{O}$ and $\mathrm{CO}_{2}$ formation. Then the formed intermediate products react with the remain methane through the steam or dry reforming of methane reactions and finally generate $\mathrm{H}_{2}$ and $\mathrm{CO}$. The numerical simulation also showed that the $\mathrm{H}_{2}$ and $\mathrm{H}_{2} \mathrm{O}$ addition into reaction mixture result significant decrease of the surface carbon deposition. However, $\mathrm{H}_{2} \mathrm{O}$ inhibited better carbon deposition compared to $\mathrm{H}_{2}$. The authors suggested that the proposed kinetic model can be apply in industry to design the process conditions and evaluation of the effect of the inlet gas composition to syngas production including the elimination of the deactivation process and coke deposition on catalytic surface.

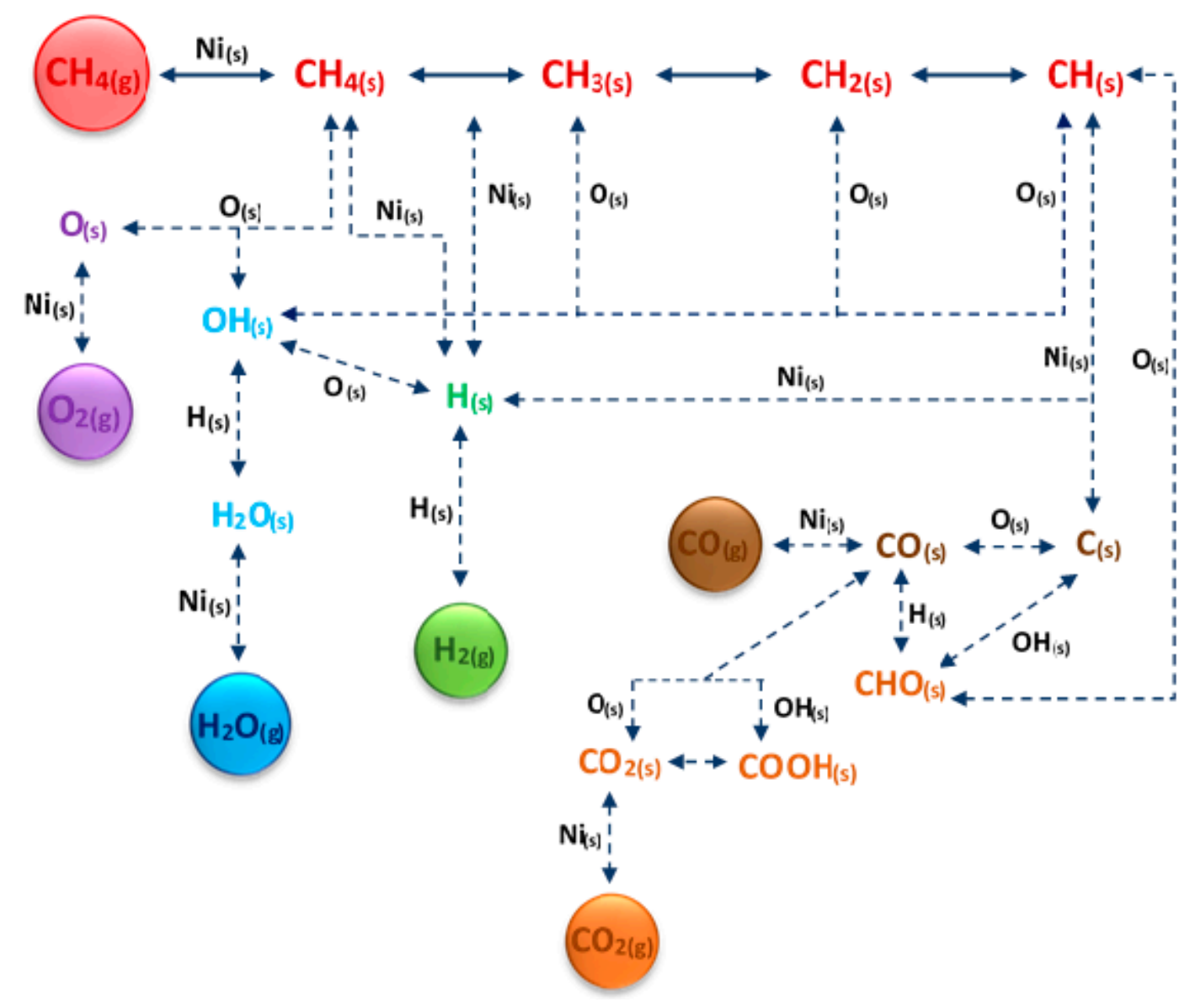

Figure 6. The methane oxidation and reforming reactions pathways performed on nickel based catalyst [110].

Souza et al. [114] studied the mechanism of the autothermal reforming of methane over nickel based catalysts (ATR). They reported about the high rates of methane conversions at lower temperature compared to the methane reforming processes and that synthesis gas is produced via two steps which includes total oxidation of methane followed by steam reforming of methane and dry reforming of methane. They also agree with the postulated in the literature data tendency that firstly combustion process took place near the entrance of the bed and subsequently reforming reactions running through the catalytic bed after total consumption of oxygen. Due to the combustion zone and the presence of hot spots which are one of the main disadvantages of the partial oxidation. Authors also indicate that in the case of the oxygen presence, during the process created metallic nickel is oxidized and only the combustion reaction occurs on its surface. While, the lack of oxygen leads to the progress of the methane reforming reaction on the remaining metallic nickel centers. Authors claimed also about the possibility of the limitation of hot spots by the combination of the SRM with POM processes in one act. 
This is achieved by the adjusting the partial pressure ratio of $\mathrm{CH}_{4}, \mathrm{O}_{2}$, and $\mathrm{H}_{2} \mathrm{O}$ during the conducting the process. Another important issue of the ATR process is deposit formation or coking. In order to avoid carbon deposit, the steam content in the reaction mixture must be increased. The authors emphasized that the reactions whose rates are significant in terms of experimental results should be considered. ATR being a combination of POM and SRM process during which the following reactions take place: partial oxidation of methane, total oxidation of methane, dry reforming, deposition of carbon from carbon monoxide, cracking of methane, water-gas shift reaction and gasification of carbon by oxygen. Taking into account of the thermodynamic conditions a proposed mechanism of the ATR process realized on the Ni based catalyst consists of six reaction steps presented in Figure 7.

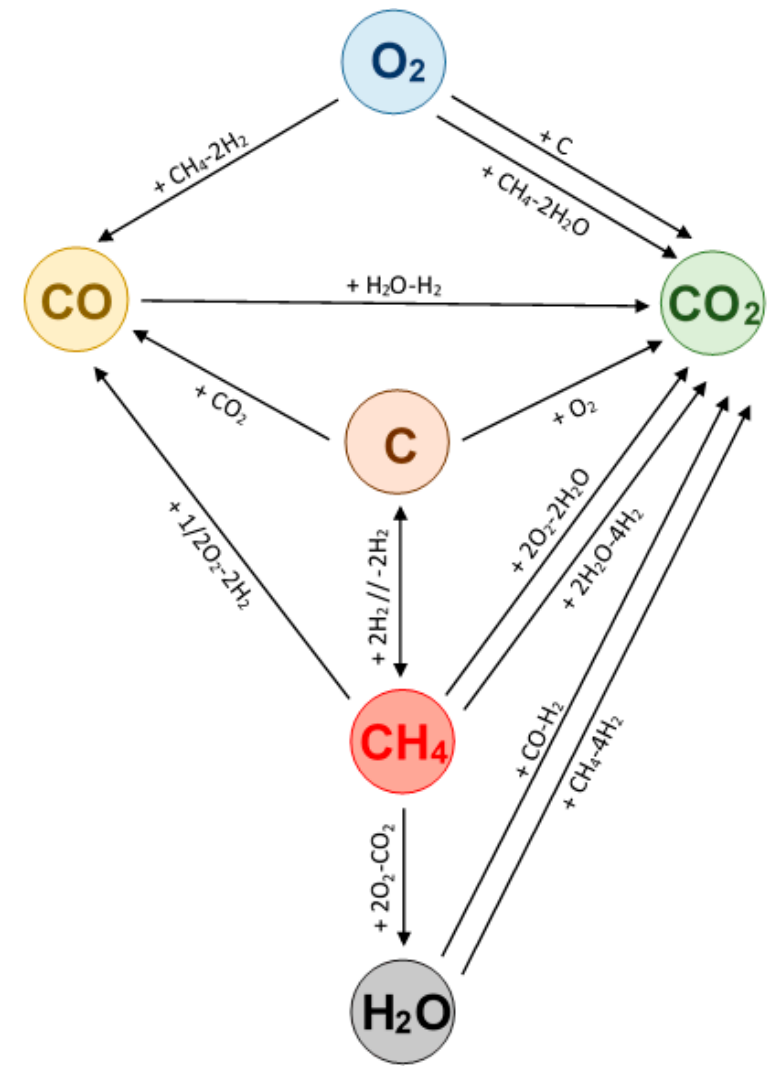

Figure 7. Scheme of the reactions running during the ATR process on Ni catalyst $[113,114]$.

\section{The Catalytic Material Used in the Oxy-Steam Reforming of Methane/LNG Process}

The crucial role in hydrogen or syngas production processes play catalytic materials which application influence on efficiency of the oxy - steam reforming of methane. Today, the impregnation method is still the most common technique to obtain catalyst systems. Despite of the fact that this preparation method give a catalyst with a tendency to sintering and coking it's still the most popular method for the preparation of the metal based catalysts. The impregnation method is still accepted in industry due to its simplicity. However, this preparation technique is currently modified and adapted to various requirements. The recent literature show that the new strategies for impregnation method appears which goal is to obtain better dispersion and smaller particles of active metal on the catalyst surface. The main changes are related with the use of a different impregnating solvent, which is often water, but also organic compounds or by changing of metal precursors [28,115-118]. However, the high cost, complexity and dangerous consequences for environmental of this changes resulting from toxic of some compounds [38]. The catalysts used in the oxy - steam reforming of methane process should be characterize a high activity and stability in the tested reaction. Designed catalytic materials need to be resistant to carbon deposit and exhibit thermal stability. Catalyst deactivation can also be 
due to poisoning process result in decreasing of their activity in reforming processes. Nickel is the most popular transition metal catalyst used in the oxy - steam reforming of methane process [119-122]. The wide use of the nickel based catalysts can be explain by their low cost and satisfactorily activity in the tested reaction. The nickel content in the catalyst system usually not exceed $20 \%$ because this is optimum Ni content above which the activity not increase further. The decrease of the catalytic activity may be explained by the nickel dispersion which decreases as the nickel content increases. Typically, the nickel particles are in range $20-50 \mathrm{~nm}$ and Ni dispersion degree exhibit 2-5\% [107]. The active phase of the catalyst is often supported on various oxides which are tailor to established requirements. The most widely used as support of nickel catalyst is $\alpha-\mathrm{Al}_{2} \mathrm{O}_{3}$ oxide which exhibit thermal stability and relative low costs. Except for $\alpha /(\gamma)-\mathrm{Al}_{2} \mathrm{O}_{3}$, other common oxide supports are $\mathrm{MgO}, \mathrm{MgAl}_{2} \mathrm{O}_{4}$, $\mathrm{SiO}_{2}, \mathrm{ZrO}_{2}, \mathrm{CeO}_{2}$ and $\mathrm{TiO}_{2}$, respectively. The $\alpha-\mathrm{Al}_{2} \mathrm{O}_{3}$ is used as a support because improve the mechanical strength and prevent catalyst sintering. In addition, aluminium oxide exhibit high specific surface area and strong metal - support interactions that can reduce the activity of nickel catalysts. Moreover, $\mathrm{Ni} / \mathrm{Al}_{2} \mathrm{O}_{3}$ catalyst exhibit low stability during the reforming of methane reaction due to carbon deposit formation. The $\alpha-\mathrm{Al}_{2} \mathrm{O}_{3}$ support is also high sensitivity on temperature above $973 \mathrm{~K}$. High temperature processing of $\alpha-\mathrm{Al}_{2} \mathrm{O}_{3}$ can lead to its sintering and pore blocking. On the other hand to high temperature of the catalyst pre-treatment cause the decrease of the surface area and the phase transformation of $\mathrm{Al}_{2} \mathrm{O}_{3}$. These properties leads to conclusions that it is necessary to modify the $\mathrm{Al}_{2} \mathrm{O}_{3}$ support to obtain thermal stable catalyst in reforming of methane reactions. Therefore, the researchers intensively studied the influence of various oxides addition to $\mathrm{Al}_{2} \mathrm{O}_{3}$ on activity and selectivity of nickel catalysts in methane reforming processes $[40,123,124]$. It should be emphasized that the main role of the support is to provide catalytically active, large and stable surface for an active phase. The support should exhibit developed porosity which lead to better contact between reactants and catalyst surface. The morphology, porosity and transition phase of the support determine the active metal particle size. In addition, the interaction between the metal and support component and the nature of chemical bonding influence on the reactivity of Ni catalyst. Also it is well known that the acidity of the catalyst surface facilitate the methane decomposition at the same time leading to cracking and polymerization which can promote carbon deposition. Another example of modifying the properties of the carrier material extensively used in methane reforming processes is the introduction of transition metals oxide such as: $\mathrm{CeO}_{2}, \mathrm{La}_{2} \mathrm{O}_{3}, \mathrm{ZrO}_{2}$ and $\mathrm{Cr}_{2} \mathrm{O}_{3}$ into alumina network [125-127]. This modification changes the oxygen storage capacity increasing activity and resistance to deactivation of the catalyst by deposition of coke. Researchers of the work [127] investigated the addition of La, Mg, $\mathrm{Co}$ and $\mathrm{Zn}$ effect on the catalytic activity and stability of the monometallic Ni catalyst supported on $\mathrm{SiO}_{2}$ in dry reforming of methane reaction. The authors based on their results reported that the addition of $\mathrm{La}$ increases the dispersion of $\mathrm{NiO}$ which leads to increased activity in the investigated process. The $\mathrm{CeO}_{2}$ oxide is also wide used as a catalyst support for Ni catalysts. The literature data reports that the $\mathrm{CeO}_{2}$ addition to nickel catalysts improve their stability and reduce carbon deposit formation [128]. The addition of cerium oxide also influences on the reactivity of the catalyst and facilitates the dispersion of the active phase. $\mathrm{CeO}_{2}$ oxide stabilize the $\mathrm{Al}_{2} \mathrm{O}_{3}$ support, improves reduction properties of the $\mathrm{Ni}$ catalyst and has high ability to transfer oxygen $[129,130]$. $\mathrm{ZrO}_{2}$ oxide is also well known as a support itself or often used as an oxide additive to $\mathrm{Ni}$ based systems. It is well known, that the zirconium oxide improves nickel dispersion, neutralize the acidity of the catalyst surface and increase its stability. Furthermore, the catalyst containing $\mathrm{ZrO}_{2}$ exhibited a high efficiency toward hydrogen production in oxy - steam reforming of methane process [131,132]. Hyun-Seog Roh at al. [40] investigated the $\mathrm{Ni}$ catalysts supported on $\mathrm{MgO}, \mathrm{CeO}_{2}, \mathrm{ZrO}_{2}, \mathrm{Ce}-\mathrm{ZrO}_{2}$ and $\mathrm{MgAl}_{2} \mathrm{O}_{4}$ in oxidative steam reforming of methane reaction. The mentioned catalyst systems were examined at $750{ }^{\circ} \mathrm{C}$ in OSR of methane reaction. Their activity were expressed as a $\mathrm{CH}_{4}$ conversion and presented in function of $\mathrm{O}_{2} / \mathrm{CH}_{4}$ ratio. This test exhibited that $\mathrm{Ni} / \mathrm{MgAl}_{2} \mathrm{O}_{4}$ catalyst showed high $\mathrm{CH}_{4}$ conversion (93\%) at $\mathrm{O}_{2} / \mathrm{CH}_{4}$ ratio equal 0.5 , respectively. The methane conversion for this catalyst decreased with decreasing of $\mathrm{O}_{2} / \mathrm{CH}_{4}$ ratio and when is equal 0.2 the catalyst undergo deactivated with time. The activity results showed 
that $\mathrm{Ni} / \mathrm{MgAl}_{2} \mathrm{O}_{4}$ catalyst is susceptible for carbon deposit formation. In the oxy - steam reforming of methane reaction the activity of the investigated catalysts expressed as a methane conversion can be presented in the following series: $\mathrm{Ni} / \mathrm{ZrO}_{2}<\mathrm{Ni} / \mathrm{MgO}<\mathrm{Ni} / \mathrm{MgAl}_{2} \mathrm{O}_{4}<\mathrm{Ni} / \mathrm{CeO}_{2}<\mathrm{Ni} / \mathrm{Ce}-\mathrm{ZrO}_{2}$. The $\mathrm{Ni} / \mathrm{Ce}-\mathrm{ZrO}_{2}$ catalyst showed the highest activity and stability in OSR of methane reaction among all tested catalytic systems. It is a result of the synergistic effect of Ce addition to $\mathrm{ZrO}_{2}$ support and strong interaction between nickel and support components. Additionally, the cerium addition also improves oxygen storage capacity and facilitates the production of mobile oxygen during the OSR of methane process. In further investigations authors [133] determined the influence on Ni content on the physicochemical and catalytic activity of $\mathrm{Ni} / \mathrm{Ce}-\mathrm{ZrO}_{2}$ catalyst in the oxy - steam reforming of methane reaction. They reported that methane conversion increase with increasing of the nickel content up to $15 \mathrm{wt}$. \% and above this value decrease. The $15 \% \mathrm{Ni} / \mathrm{Ce}-\mathrm{ZrO}_{2}$ catalyst was the most active system in OSR of methane process. Authors explain the obtained results by the present of two kind of active sites present on the catalyst surface. The first type of active centres is responsible for the activation of methane and the second one for steam or oxygen activation. Furthermore, the activity results showed that the OSR of methane process can be performed over $15 \% \mathrm{Ni} / \mathrm{Ce}-\mathrm{ZrO}_{2}$ catalyst safely along with high efficiency. Despite of the high activity and stability of $\mathrm{Ni} / \mathrm{Ce}-\mathrm{ZrO}{ }_{2}$ catalyst this catalytic system can be difficult to commercialize due to the high price of $\mathrm{Ce}-\mathrm{ZrO}_{2}$ support. Therefore, in further investigation authors of the work [134] decrease of $\mathrm{Ce}-\mathrm{ZrO}_{2}$ content in the catalytic system by the addition of $\theta-\mathrm{Al}_{2} \mathrm{O}_{3}$ oxide. For comparison purposes, Ni catalyst supported only on $\theta-\mathrm{Al}_{2} \mathrm{O}_{3}$ and $\gamma-\mathrm{Al}_{2} \mathrm{O}_{3}$ oxides were also prepared. In the case of $\mathrm{Ni} / \mathrm{Ce}-\mathrm{ZrO}_{2} / \theta-\mathrm{Al}_{2} \mathrm{O}_{3}$ system the $\mathrm{NiO}_{\mathrm{x}}$ species strongly interact with the carriers, and do not form a spinel $\mathrm{NiAl}_{2} \mathrm{O}_{4}$ or occur as a free $\mathrm{NiO}_{\mathrm{x}}$ species on the catalyst surface. These fact explained that $\mathrm{Ni} / \mathrm{Ce}-\mathrm{ZrO}_{2} / \theta-\mathrm{Al}_{2} \mathrm{O}_{3}$ catalyst exhibited high activity and stability in oxy - steam reforming of methane reaction. In addition, authors reported that $\mathrm{Ce}-\mathrm{ZrO}_{2}$ addition to $\mathrm{Ni} / \mathrm{Al}_{2} \mathrm{O}_{3}$ catalysts has a beneficial effects on $\mathrm{Ni}$ catalysts properties. This effect improves the content of the mobile oxygen in the catalytic system and prevent $\mathrm{NiAl}_{2} \mathrm{O}_{4}$ spinel formation which is hardly to reduce. The results showed that the optimum content of nickel in the investigated catalytic systems was $12 \mathrm{wt}$. \% of Ni. Catalyst with $12 \mathrm{wt}$. \% of Ni had the best efficiency in OSR of methane process. In our previous work [135], we studied the physicochemical and catalytic properties of nickel catalyst supported on $\mathrm{ZrO}_{2}, 5 \% \mathrm{La}_{2} \mathrm{O}_{3}-\mathrm{ZrO}_{2}$ and $5 \% \mathrm{CeO}_{2}-\mathrm{ZrO}_{2}$ systems in oxy - steam reforming of methane reaction. The catalytic activity tests performed in OSR of methane process showed that the most active system was $20 \% \mathrm{Ni} / \mathrm{ZrO}_{2}$. This catalyst exhibited high $\mathrm{CH}_{4}$ conversion and hydrogen yield production. The high activity was explained by the strong interaction between $\mathrm{NiO}$ and $\mathrm{ZrO}_{2}$ components which was confirmed by TPR measurements and ToF-SIMS techniques. We also modified the $\mathrm{ZrO}_{2}$ support by $5 \% \mathrm{La}_{2} \mathrm{O}_{3}$ and $5 \% \mathrm{CeO}_{2}$ oxides. The results concerning investigative catalysts proved that $\mathrm{CeO}_{2}$ addition to $\mathrm{Ni} / \mathrm{ZrO}_{2}$ catalyst leads to formation smaller $\mathrm{NiO}$ particles on the catalyst surface. The activity results in OSR of methane showed that $20 \% \mathrm{Ni} / 5 \% \mathrm{La}_{2} \mathrm{O}_{3}-\mathrm{ZrO}_{2}$ and $20 \% \mathrm{Ni} / \mathrm{ZrO}_{2}$ catalysts exhibited the highest methane conversion at $700{ }^{\circ} \mathrm{C}$ about $97 \%$. The $20 \% \mathrm{Ni} / 5 \% \mathrm{CeO}_{2}-\mathrm{ZrO}_{2}$ system exhibited lower $\mathrm{CH}_{4}$ conversion at $700{ }^{\circ} \mathrm{C}$ but the highest hydrogen yield compared to the other studied catalytic systems. In other work [136] we studied physicochemical and catalytic properties of catalysts containing $5 \mathrm{wt}$. \% of $\mathrm{Ni}$ supported on various carriers such as: $\mathrm{La}_{2} \mathrm{O}_{3}, \mathrm{CeO}_{2}, \mathrm{ZrO}_{2}$, $\mathrm{CeO}_{2} \cdot \mathrm{La}_{2} \mathrm{O}_{3}(2: 1,1: 1,1: 2), \mathrm{CeO}_{2} \cdot \mathrm{ZrO}_{2}(2: 1)$ and $\mathrm{La}_{2} \mathrm{O}_{3} \cdot \mathrm{ZrO}_{2}(2: 1)$. The activity tests showed that the $5 \% \mathrm{Ni} / \mathrm{CeO}_{2}$ catalyst exhibited the highest value of methane conversion in the studied temperature range. However, the $5 \% \mathrm{Ni} / \mathrm{ZrO}_{2}$ system showed the highest hydrogen selectivity and $\mathrm{H}_{2} / \mathrm{CO}$ ratio compared to the other studied catalysts supported on monoxide. The lowest activity in OSR of methane reaction exhibited $\mathrm{Ni} / \mathrm{La}_{2} \mathrm{O}_{3}$ catalyst. Authors also optimized the binary oxides support composition containing $\mathrm{La}_{2} \mathrm{O}_{3}, \mathrm{CeO}_{2}$ and $\mathrm{ZrO}_{2}$ oxides. The nickel catalyst with the highest content of $\mathrm{La}_{2} \mathrm{O}_{3}$ in the support exhibited the lowest methane conversion. In the case of $5 \% \mathrm{Ni} / \mathrm{CeO}_{2} \cdot \mathrm{La}_{2} \mathrm{O}_{3}(1: 2)$ catalyst we did not observed $\mathrm{H}_{2}$ and $\mathrm{CO}$ formation at $700{ }^{\circ} \mathrm{C}$ in OSR of methane process. Moreover, the $5 \% \mathrm{Ni} / \mathrm{CeO}_{2} \cdot \mathrm{La}_{2} \mathrm{O}_{3}(2: 1)$ system exhibited the highest activity in studied reaction and present the highest $\mathrm{CH}_{4}$ conversion and $\mathrm{H}_{2}$ to $\mathrm{CO}$ ratio at $700{ }^{\circ} \mathrm{C}$ in the oxy - steam reforming of methane process. 
The obtained catalytic activity results showed that increasing of lanthanum content in catalytic system cause decrease of the activity of nickel catalyst due to $\mathrm{LaNiO}_{3}$ formation. Authors reported that the developed catalyst systems in this work may found the application in industry for hydrogen production via oxy - steam reforming of methane process. The authors of the work [137] studied the promotion effect of silver on $20 \% \mathrm{Ni} / \mathrm{ZrO}_{2}$ catalysts in OSR of methane process. Silver content in the bimetallic catalysts was $0.5,1$ and $2 \%$ by weight. It was found that silver addition to monometallic nickel catalyst result in decrease of $\mathrm{CH}_{4}$ conversion. Only in the case of $2 \% \mathrm{Ag}-20 \% \mathrm{Ni} / \mathrm{ZrO} \mathrm{Z}_{2}$ system authors confirmed the increase of the hydrogen yield at $700{ }^{\circ} \mathrm{C}$ in OSR of methane process. Moreover, the monometallic $20 \% \mathrm{Ni} / \mathrm{ZrO}_{2}$ catalysts exhibited the highest activity and hydrogen yield at $700{ }^{\circ} \mathrm{C}$ in OSR of methane reaction compared to the investigated bimetallic catalytic systems. The obtained results did not proved the promotion effect of silver on catalytic efficiency in the studied process. Stawowska et al. [138] carried out theoretical studies of deactivation process for monometallic Ni, Pd, $\mathrm{Cu}$ and Ag catalysts, the results showed that nickel catalyst has the greatest tendency to form carbon deposits. The carbon atoms located on the edge of the unit cell of Ni show a binding energy above $9 \mathrm{eV}$, while in the case of $\mathrm{Ag}$ and $\mathrm{Cu}$ catalysts, the energy was 3-5 eV. Moreover, in the case of nickel catalysts carbon deposit formed on the surface of $\mathrm{Ni}$ incorporated in its structure, while in the case of $\mathrm{Ag}$ or $\mathrm{Cu}$ catalysts $\mathrm{C}$ atom protrudes approximately $0.5-1 \AA$ above the surface of the metal what makes this kind of carbon deposit easier to remove. The results of theoretical and experimental studies allow concluding that the reduction of nickel catalyst deactivates it due to coke deposition achieved through modification of topography of the active sites. Dantas et al. [139] studied the effect of Ag, $\mathrm{Fe}, \mathrm{Pt}$ and $\mathrm{Pd}$ addition on the catalytic activity in the mixed oxygen - steam reforming of methane. The authors found that the silver-promoted catalyst was characterized by high methane conversion and stability during the process (reaction time was $24 \mathrm{~h}$ ). Keiichi Tomishige [39] investigated the nickel and platinum catalysts supported on $\gamma-\mathrm{Al}_{2} \mathrm{O}_{3}$ and bimetallic $\mathrm{Ni}-\mathrm{Pt} / \gamma-\mathrm{Al}_{2} \mathrm{O}_{3}$ prepared by subsequent and co-impregnation methods. Author reported that catalyst promoted by noble metal exhibited limiting tendency to the formation of hot spots in the catalyst and showed higher resistance of carbon deposit formation in OSR of methane process. Also, the results confirmed that catalysts prepared by subsequent impregnation method were more suitable than systems prepared by co-impregnation. This tendency was explained by the segregation of the noble metal atoms on the catalyst surface of $\mathrm{Pt}-\mathrm{Ni}$ catalysts. Additionally, the $2.6 \% \mathrm{Ni} / \gamma-\mathrm{Al}_{2} \mathrm{O}_{3}$ catalyst exhibited the highest $\mathrm{H}_{2} / \mathrm{CO}$ ratio compare to rest of the studied systems in OSR of methane process. Antonio Vita et al. [140] investigated the $\mathrm{Me} / \mathrm{CeO}_{2}(\mathrm{Me}=\mathrm{Rh}, \mathrm{Pt}, \mathrm{Ni})$ catalyst coated on cordierite monoliths in oxy - steam reforming of methane reaction. The activity results showed that studied systems exhibited very good activity in OSR of methane process. Only Ni/ $\mathrm{CeO}_{2}$ catalyst showed decreased of the stability related with the formation of encapsulated carbon and carbon whiskers on the catalyst surface due to sintering process. The used of monoliths improves the catalyst performance in OSR of methane reaction. The activity of the studied systems can be described by the following row: $\mathrm{Ni}<\mathrm{Pt}<\mathrm{Rh}$. The final reactor performance for OSR of methane process depended on the physicochemical properties of deposited active layers on the catalyst surface. Antonio Vita et al. [141] also studied the physicochemical and catalytic properties of $\mathrm{Ru} / \gamma-\mathrm{Al}_{2} \mathrm{O}_{3}$ catalyst loaded on structured cordierite monoliths in the oxy - steam reforming of methane process. The obtained results showed that $6.5 \mathrm{mg} \mathrm{cm}^{-2}$ of catalytic layer loaded on the bare monolith was enough to reached the good activity and stability in the tested reaction. The $\mathrm{Ru} / \gamma-\mathrm{Al}_{2} \mathrm{O}_{3}$ catalyst showed high $\mathrm{CH}_{4}$ conversion and hydrogen concentration equal $98 \%$ and $68 \%$, respectively. Additionally, the by-products and carbon deposits did not form during the OSR of methane reaction. The used of monoliths improves the performance in OSR of methane process notably at high flow rates. Moreover, the authors assign to monolith structure the properties which minimalize the traditional problems with reactors. They reported that monolith characterized by the large and open front area, the high area to volume ratio, good mass and heat transfer and low pressure fall, which allow for process intensification. Wen-Sheng Dong et al. [89] investigated $\mathrm{Ni} / \mathrm{MgO}$ catalyst in POM, SRM and OSR of methane processes. They claimed that $\mathrm{Ni} / \mathrm{MgO}$ system exhibited high activity and stability 
in methane reforming reactions such as: POM, SRM and OSR of methane. The investigated catalyst showed interaction between $\mathrm{NiO}$ and $\mathrm{MgO}$ compounds. They also reported that the carbon and $\mathrm{H}_{2}$ products are formed in dissociative activation of methane process on metallic Ni active sites. Further, carbon undergo oxidation to $\mathrm{CO}$. The methane steam reforming reaction that runs in parallel with the POM reaction prevents the possibility of explosion in partial oxidation of methane reaction. Authors reported also that $\mathrm{Ni} / \mathrm{MgO}$ catalyst exhibited high activity in OSR of methane process reached the $\mathrm{CH}_{4}$ conversion and $\mathrm{H}_{2} / \mathrm{CO}$ ratio equal $91.5 \%$ and 3.3, respectively. Kaori Yoshida et al. [142] studied $\mathrm{Ni} / \alpha-\mathrm{Al}_{2} \mathrm{O}_{3}$ catalysts modified by precious metals such as: $\mathrm{Pd}, \mathrm{Pt}, \mathrm{Au}, \mathrm{Ir}, \mathrm{Rh}$ and $\mathrm{Ru}$ in OSR of methane process and they found that palladium modified nickel catalyst was the most active in the investigated reaction. However, the monometallic $\mathrm{Pd} / \alpha-\mathrm{Al}_{2} \mathrm{O}_{3}$ catalyst showed to be not suitable to OSR of methane process. It was proved that the monometallic $\mathrm{Au} / \alpha-\mathrm{Al}_{2} \mathrm{O}_{3}$ catalyst was not active in OSR of methane reaction but bimetallic Au-Ni catalyst showed high methane conversion and $\mathrm{H}_{2}$ to $\mathrm{CO}$ ratio equal $99 \%$ and 2.8, respectively. In addition, the bimetallic noble metal - nickel catalysts exhibited higher $\mathrm{H}_{2} / \mathrm{CO}$ ratio compared to monometallic noble metal $/ \alpha-\mathrm{Al}_{2} \mathrm{O}_{3}$ catalysts. The highest activity of bimetallic catalysts is related with the fact, that palladium maintain the reduced state of $\mathrm{Ni}$ and prevents catalyst oxidation. A small Pd clusters present on the bimetallic catalyst surface exhibited weak interaction with nickel. Authors reported that to strong interaction between noble metal and Ni result in isolation of precious metal and their reduction behaviour has no influence during the process. Authors reported that to strong interaction between noble metal and Ni result in isolation of precious metal and their occurrence on the surface has no influence on reduction behaviour of bimetallic catalysts and on activity during the process. Hosseini et al. [38] investigated the influence of catalyst preparation methods on catalyst activity in oxy - steam reforming of methane reaction on Ni systems. They tested nickel catalyst supported on $\gamma-\mathrm{Al}_{2} \mathrm{O}_{3}$ catalysts prepared by traditional wet impregnation and microwave assistance impregnation methods and found that catalyst prepared by microwave method exhibited higher activity in the investigated reaction. The $\mathrm{CH}_{4}$ conversion and $\mathrm{H}_{2} / \mathrm{CO}$ ratio for this catalytic system were $99 \%$ and 3.2, respectively. The microwave heating applied during drying process in the preparation step of the catalyst results in high dispersion of Ni species on the surface. Additionally, microwave radiation increase the rate of $\mathrm{Ni}$ deposition on the surface of the support during the catalyst preparation. Hosseini et al. [143] investigated the nickel catalyst supported on $\mathrm{SiO}_{2}$ prepared by the conventional impregnation and oleylamine $(\mathrm{OAm})$ assisted impregnation methods. The specific surface area results showed that the $(\mathrm{OAm})-\mathrm{Ni} / \mathrm{SiO}_{2}$ catalyst system exhibited higher BET surface area compared to (IMP) - $\mathrm{Ni} / \mathrm{SiO}_{2}$ catalyst synthesized by conventional impregnation method. The $\mathrm{X}$-ray diffraction analysis and calculation based on the Scherrer equation showed that the $\mathrm{NiO}$ crystallites size of $(\mathrm{OAm})-\mathrm{Ni} / \mathrm{SiO}_{2}$ catalyst are smaller compared to the other investigated catalyst. This findings indicate that $\mathrm{NiO}$ species present on the catalyst surface of $(\mathrm{OAm})-\mathrm{Ni} / \mathrm{SiO}_{2}$ are highly dispersed in contrast to aggregated $\mathrm{NiO}$ species which are formed on the catalyst surface of (IMP) - $\mathrm{Ni} / \mathrm{SiO}_{2}$ after calcination process. Table 3 showed the stability results for $10 \mathrm{~h}$ of the oxy - steam reforming of methane reaction performed for studied catalytic systems. Authors reported that the methane conversion significant decreased after $10 \mathrm{~h}$ of the reaction for (IMP) - $\mathrm{Ni} / \mathrm{SiO}_{2}$ catalyst (from $82 \%$ to $47 \%$ ). Whereas, the $\mathrm{CH}_{4}$ conv. value was stable within $10 \mathrm{~h}$ of OSRM reaction for (OAm) - Ni/SiO 2 system. It was found that the $\mathrm{NiO}$ species occurring on the surface of (IMP) - $\mathrm{Ni} / \mathrm{SiO}_{2}$ system were more exposed for sintering and aggregation processes during OSRM reaction. The presented results confirmed that oleylamine (OAm) assisted impregnation method is more effective preparation method to obtain high active and stable nickel catalyst in the studied process. Also the use of $(\mathrm{OAm})$ assisted impregnation method has huge impact on the structure of the prepared catalyst in order to improve metal-support interaction and facilitation of the active phase reduction. Roh et al. [144] evaluated the influence of nickel content on activity of studied systems in reforming of methane reactions. They synthesized $x$ $\mathrm{Ni} / \theta-\mathrm{Al}_{2} \mathrm{O}_{3}$ catalysts, where $\mathrm{x}=3-15 \%$, respectively. The activity results performed in oxy - steam reforming of methane reaction showed that the increased of the nickel content to $12 \mathrm{wt}$ \% caused increase of the methane conversion value. For $15 \% \mathrm{Ni} / \theta-\mathrm{Al}_{2} \mathrm{O}_{3}$ system the $\mathrm{CH}_{4}$ conversion was relative 
low due to Ni sintering over catalyst surface. The high $\mathrm{CH}_{4}$ conversion above $90 \%$ accompanying high $\mathrm{CO}$ selectivity can be explain by RWGS reaction taking plays during OSRM process. Authors also studied these catalytic systems in SRM and ORM reactions. The $\mathrm{Ni} / \theta-\mathrm{Al}_{2} \mathrm{O}_{3}$ catalysts, where the $\mathrm{Ni}$ content was in the range $6-15 \mathrm{wt}$. \% of Ni exhibited high activity and stability in SRM, ORM and OSRM processes. They considered that this behaviour is explained by the strong interaction between active phase and support and the presence of stable $\mathrm{NiO}_{x}$ species on the catalyst surface. In the case of all investigated reactions, the $12 \% \mathrm{Ni} / \theta-\mathrm{Al}_{2} \mathrm{O}_{3}$ catalyst exhibited the highest activity. It can be explain by the good balance between free nickel and complex $\mathrm{NiO}_{x}$ species. Additionally, the oxy - steam reforming of methane reaction constitute the best alternative for hydrogen production among of all methane processing. The OSRM reaction provide safe operating conditions without need to supply of huge amount of external heat to run the process. Jimenez-Gonzalez et al. [145] also studied the activity of $\mathrm{Ni} / \gamma-\mathrm{Al}_{2} \mathrm{O}_{3}$ catalyst in the oxidative steam reforming of methane, isooctane and $\mathrm{N}$-tetradecane reactions. For comparison, authors tested the commercial $\mathrm{Rh} / \mathrm{Al}_{2} \mathrm{O}_{3}$ catalyst in these processes. In addition, the stability of the catalysts in OSR of hydrocarbons processes during $31 \mathrm{~h}$ of the reaction at $600{ }^{\circ} \mathrm{C}$ were evaluated. The investigated catalysts were stable in OSR of methane and isooctane reactions. However, the rhodium catalyst showed significant lower hydrocarbon conversion in the case of isooctane reforming process. The authors have found that in the case of the process in which heavier hydrocarbons were used the reactivity results showed decrease of the activity of the investigated catalysts. In addition, the use of heavier hydrocarbons lead to increase the possibility of carbon deposit formation on catalyst surface during reforming reaction. The nickel catalyst showed high activity and stability in the studied reactions compared to the rhodium containing system. These results were explained with the low Ni crystals size and high nickel surface area. The comparison of these processes showed that only in the case of oxidative steam reforming of methane reaction, the best efficiency with high and stable hydrogen production rate were confirmed. Miletic et al. [146] investigated nickel catalysts supported on $\mathrm{Al}_{2} \mathrm{O}_{3}, \mathrm{Al}_{2} \mathrm{O}_{3}-\mathrm{CeO}_{2}, \mathrm{Al}_{2} \mathrm{O}_{3}-\mathrm{La}_{2} \mathrm{O}_{3}$, and $\mathrm{Al}_{2} \mathrm{O}_{3}-\mathrm{CeO}_{2}-\mathrm{La}_{2} \mathrm{O}_{3}$ oxide systems. They studied the influence of support composition on the physicochemical and catalytic properties in the oxidative steam reforming of methane reaction. The studied nickel based catalysts were synthesized via the sol-gel method. The stability of these catalytic systems in OSRM reaction were also determined during $6 \mathrm{~h}$ running of the process. The obtained activity results showed that the $\mathrm{Ni} / \mathrm{Al}_{2} \mathrm{O}_{3}-\mathrm{CeO}_{2}-\mathrm{La}_{2} \mathrm{O}_{3}$ catalyst exhibited the highest activity and stability compare to other catalyst systems. The highest deactivation after $6 \mathrm{~h}$ of OSRM process exhibited $\mathrm{Ni} / \mathrm{Al}_{2} \mathrm{O}_{3}-\mathrm{La}_{2} \mathrm{O}_{3}$ catalyst. The $\mathrm{Ni} / \mathrm{Al}_{2} \mathrm{O}_{3}$ system also performed stable operation in the studied reaction, but in the last $2 \mathrm{~h}$ of the reaction some fluctuation in activity was observed for this catalyst. Authors confirmed that $\mathrm{CeO}_{2}$ and $\mathrm{La}_{2} \mathrm{O}_{3}$ addition to $\mathrm{Ni} / \mathrm{Al}_{2} \mathrm{O}_{3}$ catalyst improves its catalytic properties. They proved that cerium oxide addition allow to avoid surface sintering, improves surface oxygen mobility and catalyst stability. On the other hand, the lanthanum oxide addition mostly improves the thermal stability of the catalyst based on $\mathrm{Al}_{2} \mathrm{O}_{3}$ oxide. All of the mentioned properties affect on the reactivity properties of $\mathrm{Ni} / \mathrm{Al}_{2} \mathrm{O}_{3}-\mathrm{CeO}_{2}-\mathrm{La}_{2} \mathrm{O}_{3}$ catalyst. The coke concentration measurements formed on the catalyst surface after $6 \mathrm{~h}$ of OSRM reaction showed that it strongly depend on the support composition. The results showed that the amount of the carbon deposit formed on the catalyst surface decrease with the following row: $\mathrm{Ni} / \mathrm{Al}_{2} \mathrm{O}_{3}-\mathrm{La}_{2} \mathrm{O}_{3}>\mathrm{Ni} / \mathrm{Al}_{2} \mathrm{O}_{3}>$ $\mathrm{Ni} / \mathrm{Al}_{2} \mathrm{O}_{3}-\mathrm{CeO}_{2}>\mathrm{Ni} / \mathrm{Al}_{2} \mathrm{O}_{3}-\mathrm{CeO}_{2}-\mathrm{La}_{2} \mathrm{O}_{3}$. For $\mathrm{Ni} / \mathrm{Al}_{2} \mathrm{O}_{3}-\mathrm{La}_{2} \mathrm{O}_{3}$ system the formed amount of carbon per $\mathrm{g}$ of catalyst was equal $26.5 \mathrm{mg}$, where the $75 \mathrm{wt}$ \% of carbon were formed as filamentous coke and $25 \mathrm{wt}$. \% of carbon in the form of graphitic coke. The high $\mathrm{H}_{2} / \mathrm{CO}$ ratio confirmed the running of WGS reaction during the OSRM process. Authors also have mentioned on the role of acid centres, especially strong sites, which proper amount is required to obtain high catalytic activity in OSRM process.

In the case of liquefied natural gas (LNG) reforming processes the most works concerns steam reforming of LNG reaction [22,28,30,35,41,147-149]. The oxy - steam reforming of LNG process is relatively rarely investigated nowadays. To our knowledge, there are not works concerning the oxy steam reforming of LNG process carried out over Ni heterogeneous catalysts. In Table 4 we present the 
results of the physicochemical and catalytic properties of $\mathrm{Ni}$ catalysts tested in the oxy-steam reforming of LNG. The BET surface area, degree of the NiO reduction, metal particle size, preparation method and catalytic properties of currently known catalysts tested in the oxy - steam reforming of LNG reaction are given in Table 4. Mierczynski et al. [135] studied mentioned above catalytic systems not only in the oxy - steam reforming of methane but also in OSR of LNG process. They were evaluated the activity and stability of nickel catalysts supported on $\mathrm{ZrO}_{2}, 5 \% \mathrm{CeO}_{2}-\mathrm{ZrO}_{2}$ and $5 \% \mathrm{La}_{2} \mathrm{O}_{3}-\mathrm{ZrO}_{2}$ in the oxy steam reforming of LNG reaction. The activity results showed that all investigated catalytic systems exhibited total ethane, propane and butane conversion at $700{ }^{\circ} \mathrm{C}$. The $20 \% \mathrm{Ni} / 5 \% \mathrm{La}_{2} \mathrm{O}_{3}-\mathrm{ZrO}_{2}$ catalyst reached the highest values of $\mathrm{H}_{2}$ yield and $\mathrm{H}_{2}$ to $\mathrm{CO}$ ratio equal $61 \%$ and 2.2, respectively. The studied catalytic systems also exhibited the good stability during $12 \mathrm{~h}$ of the oxy - steam reforming of LNG process. The highest methane conversion value in OSR-LNG was confirmed for $20 \% \mathrm{Ni} / \mathrm{ZrO} \mathrm{Cr}_{2}$ system (98\%). However, further investigations showed that addition of silver to $20 \% \mathrm{Ni} / \mathrm{ZrO}_{2}$ catalyst result in significant decreasing of the $\mathrm{CH}_{4}$ conversion value (72\%) but also a significant increase of $\mathrm{H}_{2} / \mathrm{CO}$ ratio (3.2). The catalytic studies performed over $\mathrm{Ni}$ and $\mathrm{Ag}-\mathrm{Ni}$ catalysts showed that promotion of $20 \%$ $\mathrm{Ni} / \mathrm{ZrO}_{2}$ catalyst by silver improves its selectivity towards hydrogen yield. An undoubted advantage of silver promotion of $\mathrm{Ni}$ system is improvement of the resistance to carbon deposition of bimetallic catalysts in OSR of LNG compared to Ni system. In addition, silver addition to monometallic nickel catalyst facilitates the reducibility of the $\mathrm{NiO}$ species.

Based on the presented data concerning the catalytic material used in OSR of methane and LNG it can be summed up that the selection of appropriate catalyst for the reforming process is complicated (see Figure 8). The optimization of the catalytic material should be based on selection of suitable catalyst components to provide the appropriate physicochemical, mechanical and catalytic properties of Ni catalyst. Especially, carrier itself for the investigated process should composed of a mixture of previously selected mono- oxides characterized by the desirable properties. A catalytic material for OSR process should be characterized by high activity, selectivity and stability in the reforming of natural or liquefied natural gas. The data presented in the review will facilitate the selection of the appropriate catalyst for the reforming of natural or liquefied natural gas [137]. 
Table 3. The physicochemical and catalytic characterization of the catalytic systems applied in the OSR of the methane reaction.

\begin{tabular}{|c|c|c|c|c|c|c|c|c|c|c|c|c|}
\hline Catalyst & $\begin{array}{l}\text { Preparation } \\
\text { Method }\end{array}$ & $\begin{array}{c}\mathrm{S}_{\mathrm{BET}} \\
{\left[\mathrm{m}^{2} / \mathrm{g}\right]}\end{array}$ & $\begin{array}{c}\text { Reduction } \\
\text { of } \mathrm{NiO}[\%]^{*}\end{array}$ & $\begin{array}{c}\text { Active Metal } \\
\text { Dispersion [\%] }\end{array}$ & $\begin{array}{c}\text { Metal } \\
\text { Particle Size } \\
{[\text { [nm] }}\end{array}$ & $\begin{array}{l}\text { ToSR } \\
{\left[{ }^{\circ} \mathrm{C}\right]}\end{array}$ & $\begin{array}{c}\text { Catalyst } \\
\text { Weight } \\
\text { [g] }\end{array}$ & $\begin{array}{c}\mathrm{CH}_{4} \\
\text { Conv. } \\
{[\%]}\end{array}$ & $\mathbf{H}_{2}$ & $\mathrm{CO}$ & $\mathrm{CO}_{2}$ & $\begin{array}{r}\mathrm{H}_{2} \\
/ \mathrm{CO}\end{array}$ \\
\hline $\mathrm{Ni}(5) / \mathrm{La}_{2} \mathrm{O}_{3}[136]$ & IP & 9 & - & - & - & 700 & 0.2 & 39 & $0^{\mathrm{s}}$ & $0^{\mathrm{s}}$ & $54^{\mathrm{s}}$ & 0 \\
\hline $\mathrm{Ni}(5) / \mathrm{CeO}_{2}[136]$ & IP & 17 & - & - & - & 700 & 0.2 & 100 & $61^{\mathrm{s}}$ & $34^{\mathrm{s}}$ & $5^{\mathrm{s}}$ & 1.8 \\
\hline $\mathrm{Ni}(5) / \mathrm{ZrO}_{2}[136]$ & IP & 94 & 99 & - & - & 700 & 0.2 & 88 & $63^{s}$ & $31^{\mathrm{s}}$ & $4^{\mathrm{s}}$ & 2.0 \\
\hline $\mathrm{Ni}(5) / \mathrm{CeO}_{2} \cdot \mathrm{La}_{2} \mathrm{O}_{3}(2: 1)[136]$ & IP & 23 & - & - & - & 700 & 0.2 & 99 & $64^{\mathrm{s}}$ & $31^{\mathrm{s}}$ & $5^{\mathrm{s}}$ & 2.1 \\
\hline $\mathrm{Ni}(5) / \mathrm{CeO}_{2} \cdot \mathrm{La}_{2} \mathrm{O}_{3}(1: 1)[136]$ & IP & 25 & - & - & - & 700 & 0.2 & 98 & $64^{s}$ & $30^{s}$ & $6^{s}$ & 2.1 \\
\hline $\mathrm{Ni}(5) / \mathrm{CeO}_{2} \cdot \mathrm{La}_{2} \mathrm{O}_{3}(1: 2)[136]$ & IP & 20 & - & - & - & 700 & 0.2 & 43 & $0^{\mathrm{s}}$ & $1^{\mathrm{s}}$ & $46^{s}$ & 0 \\
\hline $\mathrm{Ni}(5) / \mathrm{CeO}_{2} \cdot \mathrm{ZrO}_{2}(2: 1)[136]$ & IP & 42 & - & - & - & 700 & 0.2 & 97 & $65^{\mathrm{s}}$ & $31^{\mathrm{s}}$ & $4^{\mathrm{s}}$ & 2.1 \\
\hline $\mathrm{Ni}(5) / \mathrm{La}_{2} \mathrm{O}_{3} \cdot \mathrm{ZrO}_{2}(2: 1)[136]$ & IP & 4 & - & - & - & 700 & 0.2 & 28 & $0^{\mathrm{s}}$ & $0^{\mathrm{s}}$ & $66^{s}$ & 0 \\
\hline $\mathrm{Ni}(20) / \mathrm{ZrO}_{2}[135]$ & IP & 77 & 80 & - & $32 * * *$ & 700 & 0.2 & 97 & $91^{\mathrm{y}}$ & $89^{s}$ & $11^{\mathrm{s}}$ & 1.7 \\
\hline $\mathrm{Ni}(20) / \mathrm{CeO}_{2}(5)-\mathrm{ZrO}_{2}[135]$ & IP & 79 & 60 & - & $24^{* * *}$ & 700 & 0.2 & 87 & $101^{y}$ & $75^{s}$ & $24^{\mathrm{s}}$ & 4.6 \\
\hline $\mathrm{Ni}(20) / \mathrm{La}_{2} \mathrm{O}_{3}(5)-\mathrm{ZrO}_{2}[135]$ & IP & 74 & 99 & - & $20^{* * *}$ & 700 & 0.2 & 97 & $90^{y}$ & $88^{\mathrm{s}}$ & $12^{\mathrm{s}}$ & 1.7 \\
\hline $\mathrm{Ag}(1)-\mathrm{Ni}(20) / \mathrm{ZrO}_{2}[137]$ & SIP & 69 & - & - & - & 700 & 0.2 & 96 & $83^{y}$ & $89^{\mathrm{s}}$ & $11^{\mathrm{s}}$ & 1.9 \\
\hline $\mathrm{Pt}(0.1) / \gamma-\mathrm{Al}_{2} \mathrm{O}_{3}[39]$ & IP & - & - & - & - & 850 & 0.08 & 87 & - & $75^{s}$ & - & 2.8 \\
\hline $\mathrm{Ni}(2.6) / \gamma-\mathrm{Al}_{2} \mathrm{O}_{3}[39]$ & IP & - & 100 & - & $4.8^{* * * *}$ & 850 & 0.08 & 97 & - & $79^{s}$ & - & 2.9 \\
\hline $\mathrm{Pt}(0.1) / \mathrm{Ni}(2.6) / \gamma-\mathrm{Al}_{2} \mathrm{O}_{3}[39]$ & SIP & - & 100 & - & $5.0^{* * * *}$ & 850 & 0.08 & $>99$ & - & $82^{s}$ & - & 2.7 \\
\hline $\mathrm{Pt}(0.1)-\mathrm{Ni}(2.6) / \gamma-\mathrm{Al}_{2} \mathrm{O}_{3}[39]$ & $\mathrm{CIP}$ & - & 100 & - & $4.5^{* * * *}$ & 850 & 0.08 & $>99$ & - & $81^{\mathrm{s}}$ & - & 2.7 \\
\hline $\mathrm{Ni}(7.5) / \mathrm{CeO}_{2}[140]$ & IP & 5 & - & $2.9 * *$ & - & 750 & - & 98 & $68^{c}$ & $19^{c}$ & $13^{c}$ & 3.2 \\
\hline $\mathrm{Rh}(1.5) / \mathrm{CeO}_{2}[140]$ & IP & 14 & - & $22.2 * *$ & - & 750 & - & 99 & $68^{c}$ & $19^{c}$ & $13^{c}$ & 3.2 \\
\hline $\mathrm{Pt}(1.5) / \mathrm{CeO}_{2}[140]$ & IP & 16 & - & $23.1^{* *}$ & - & 750 & - & 99 & $68^{c}$ & $19^{c}$ & $13^{c}$ & 3.2 \\
\hline $\mathrm{Ru}(1.5) / \gamma-\mathrm{Al}_{2} \mathrm{O}_{3}[141]$ & IP & 192 & - & $0.9^{* *}$ & $22 * * *$ & 750 & - & $>99$ & $70^{c}$ & $20^{c}$ & $10^{c}$ & 3.3 \\
\hline $\mathrm{Ni}(15) / \mathrm{MgO}$ [89] & MS & 16 & - & $1.7^{* *}$ & $58^{* *}$ & 750 & 0.05 & 92 & - & $55^{\mathrm{s}}$ & - & 3.3 \\
\hline $\mathrm{Ni}(15) / \mathrm{Ce}-\mathrm{ZrO}_{2}$ [133] & MS & 40 & 85 & $0.9^{* *}$ & $112^{* *}$ & 750 & - & 99 & - & $69 \mathrm{y}$ & - & 3.4 \\
\hline $\mathrm{Ni}(15) / \mathrm{Ce}-\mathrm{ZrO}_{2} / \theta-\mathrm{Al}_{2} \mathrm{O}_{3}[134]$ & IP & 128 & 92 & $5.0 * *$ & $11.3^{* * *}$ & 750 & 0.05 & 98 & - & $72^{s}$ & - & 3.0 \\
\hline $\mathrm{Ni}(10.6) / \alpha-\mathrm{Al}_{2} \mathrm{O}_{3}[142]$ & IP & - & - & $3.4^{* *}$ & $28^{a}$ & 850 & 0.045 & $>99$ & - & $81^{\mathrm{s}}$ & - & 2.8 \\
\hline $\mathrm{Pd}(0.07) / \alpha-\mathrm{Al}_{2} \mathrm{O}_{3}[142]$ & IP & - & - & - & - & 850 & 0.045 & 64 & - & $91^{\mathrm{s}}$ & - & 1.9 \\
\hline
\end{tabular}


Table 3. Cont.

\begin{tabular}{|c|c|c|c|c|c|c|c|c|c|c|c|c|}
\hline Catalyst & $\begin{array}{l}\text { Preparation } \\
\text { Method }\end{array}$ & $\begin{array}{c}\mathrm{S}_{\mathrm{BET}} \\
{\left[\mathrm{m}^{2} / \mathrm{g}\right]}\end{array}$ & $\begin{array}{l}\text { Reduction } \\
\text { of } \mathrm{NiO}[\%]^{*}\end{array}$ & $\begin{array}{c}\text { Active Metal } \\
\text { Dispersion [\%] }\end{array}$ & $\begin{array}{c}\text { Metal } \\
\text { Particle Size } \\
{[\text { [nm] }}\end{array}$ & $\begin{array}{c}\mathrm{T}_{\mathrm{OSR}} \\
{\left[{ }^{\circ} \mathrm{C}\right]}\end{array}$ & $\begin{array}{c}\text { Catalyst } \\
\text { Weight } \\
\text { [g] }\end{array}$ & $\begin{array}{c}\mathrm{CH}_{4} \\
\text { Conv. } \\
{[\%]}\end{array}$ & $\mathbf{H}_{2}$ & $\mathrm{CO}$ & $\mathrm{CO}_{2}$ & $\begin{array}{r}\mathrm{H}_{2} \\
/ \mathrm{CO}\end{array}$ \\
\hline $\mathrm{Pd}(0.07)-\mathrm{Ni}(10.6) / \alpha-\mathrm{Al}_{2} \mathrm{O}_{3}[142]$ & CIP & - & - & $6.6^{* *}$ & $15^{\mathrm{a}}$ & 850 & 0.045 & $>99$ & - & $81^{\mathrm{s}}$ & - & 2.8 \\
\hline $\mathrm{Pt}(0.14) / \alpha-\mathrm{Al}_{2} \mathrm{O}_{3}[142]$ & IP & - & - & - & - & 850 & 0.045 & 96 & - & $83^{s}$ & - & 2.3 \\
\hline $\mathrm{Pt}(0.14)-\mathrm{Ni}(10.6) / \alpha-\mathrm{Al}_{2} \mathrm{O}_{3}[142]$ & CIP & - & - & $4.6^{* *}$ & $21^{a}$ & 850 & 0.045 & $>99$ & - & $81^{\mathrm{s}}$ & - & 2.9 \\
\hline $\mathrm{Au}(0.14) / \alpha-\mathrm{Al}_{2} \mathrm{O}_{3}[142]$ & IP & - & - & - & - & 850 & 0.045 & $<1$ & - & - & - & - \\
\hline $\mathrm{Au}(0.14)-\mathrm{Ni}(10.6) / \alpha-\mathrm{Al}_{2} \mathrm{O}_{3}[142]$ & CIP & - & - & $2.6^{* *}$ & $23^{* * *}$ & 850 & 0.045 & $>99$ & - & $80^{\mathrm{s}}$ & - & 2.8 \\
\hline $\operatorname{Ir}(0.14) / \alpha-\mathrm{Al}_{2} \mathrm{O}_{3}[142]$ & IP & - & - & - & - & 850 & 0.045 & 93 & - & $82^{\mathrm{s}}$ & - & 2.4 \\
\hline $\operatorname{Ir}(0.14)-\mathrm{Ni}(10.6) / \alpha-\mathrm{Al}_{2} \mathrm{O}_{3}[142]$ & CIP & - & - & $3.8^{* *}$ & $26^{\mathrm{a}}$ & 850 & 0.045 & $>99$ & - & $80^{\mathrm{s}}$ & - & 2.9 \\
\hline $\mathrm{Rh}(0.07) / \alpha-\mathrm{Al}_{2} \mathrm{O}_{3}[142]$ & IP & - & - & - & - & 850 & 0.045 & $>99$ & - & $81^{\mathrm{s}}$ & - & 2.8 \\
\hline $\mathrm{Rh}(0.07)-\mathrm{Ni}(10.6) / \alpha-\mathrm{Al}_{2} \mathrm{O}_{3}[142]$ & CIP & - & - & $5.2^{* *}$ & $19^{\mathrm{a}}$ & 850 & 0.045 & $>99$ & - & $79^{\mathrm{s}}$ & - & 2.9 \\
\hline $\mathrm{Ru}(0.07) / \alpha-\mathrm{Al}_{2} \mathrm{O}_{3}[142]$ & $\mathrm{IP}$ & - & - & - & - & 850 & 0.045 & $>99$ & - & $81^{\mathrm{s}}$ & - & 2.7 \\
\hline $\mathrm{Ru}(0.07)-\mathrm{Ni}(10.6) / \alpha-\mathrm{Al}_{2} \mathrm{O}_{3}[142]$ & CIP & - & - & $4.3^{* *}$ & $23^{a}$ & 850 & 0.045 & $>99$ & - & $81^{\mathrm{s}}$ & - & 2.9 \\
\hline $\mathrm{Ni}(10) / \gamma-\mathrm{Al}_{2} \mathrm{O}_{3}[38]$ & MI & 186 & 85 & $4.6^{* * *}$ & - & 750 & 0.06 & 99 & $2.4^{\mathrm{n}}$ & $0.8^{n}$ & - & 3.2 \\
\hline $\mathrm{Ni}(10) / \gamma-\mathrm{Al}_{2} \mathrm{O}_{3}[38]$ & IP & - & - & - & - & 750 & 0.06 & 58 & $1.3^{n}$ & $0.3^{n}$ & - & 1.6 \\
\hline $\mathrm{Ni}(5) / \mathrm{SiO}_{2}[143]$ & OAmIP & 304 & - & - & $5.4^{* * *}$ & 750 & 0.1 & 92 & $2.3^{n}$ & $0.7^{n}$ & $0.2^{n}$ & 3.4 \\
\hline $\mathrm{Ni}(5) / \mathrm{SiO}_{2}[143]$ & IP & 270 & - & - & $10.8^{* * *}$ & 750 & 0.1 & 47 & $1.0^{\mathrm{n}}$ & $0.2^{n}$ & $0.3^{n}$ & 5.2 \\
\hline $\mathrm{Ni}(12) / \theta-\mathrm{Al}_{2} \mathrm{O}_{3}[144]$ & IP & 145 & 66 & $30.1^{* *}$ & $21.2^{* * *}$ & 750 & 0.05 & 99 & - & $71^{\mathrm{s}}$ & - & 3.0 \\
\hline $\mathrm{Ni}(17) / \gamma-\mathrm{Al}_{2} \mathrm{O}_{3}[145]$ & $\mathrm{CP}$ & 94 & - & - & - & 600 & 0.125 & 75 & $31^{\mathrm{y}}$ & $19^{\mathrm{y}}$ & $59 \mathrm{y}$ & - \\
\hline $\mathrm{Rh}(1) / \gamma-\mathrm{Al}_{2} \mathrm{O}_{3}[145]$ & - & 132 & - & 33 & $9^{* * *}$ & 600 & 0.125 & 90 & $50^{y}$ & $19^{y}$ & $70^{y}$ & - \\
\hline $\mathrm{Ni}(9) / \gamma-\mathrm{Al}_{2} \mathrm{O}_{3}[146]$ & SG & 126 & - & $4.4^{\mathrm{b}}$ & $4^{* * *}$ & 550 & - & 54 & $2.4^{\mathrm{s}}$ & - & - & 4.7 \\
\hline $\mathrm{Ni}(9) / \gamma-\mathrm{Al}_{2} \mathrm{O}_{3}-\mathrm{CeO}_{2}[146]$ & SG & 132 & - & $5.5^{b}$ & $5^{* * *}$ & 550 & - & 45 & $2.2^{\mathrm{s}}$ & - & - & 4.0 \\
\hline $\mathrm{Ni}(9) / \gamma-\mathrm{Al}_{2} \mathrm{O}_{3}-\mathrm{La}_{2} \mathrm{O}_{3}[146]$ & SG & 131 & - & $6.0^{\mathrm{b}}$ & $7^{* * *}$ & 550 & - & 52 & $1.4^{\mathrm{s}}$ & - & - & 3.8 \\
\hline $\begin{array}{c}\mathrm{Ni}(9) / \gamma-\mathrm{Al}_{2} \mathrm{O}_{3}-\mathrm{CeO}_{2}-\mathrm{La}_{2} \mathrm{O}_{3} \\
{[146]}\end{array}$ & SG & 127 & - & $4.7^{\mathrm{b}}$ & $4^{* * *}$ & 550 & - & 52 & $2.1^{\mathrm{s}}$ & - & - & 5.8 \\
\hline
\end{tabular}

* based on TPR- $\mathrm{H}_{2}$ measurement; ** based on Specific Surface Area $\left(\mathrm{S}_{\mathrm{BET}}\right)$ measurement; *** based on XRD measurement; ${ }^{* * * *}$ based on TEM observation; a-Estimated from equation $\frac{0.971}{\text { dispersion }} \times 100$ (the particle size of noble metals atoms is the same as the nickel atom because of very small amount of noble metals); $\mathrm{b}-$ Based on $\mathrm{H}_{2}$-pulse chemisorption measurements; IP-Impregnation method, SIP—Subsequent impregnation method, CIP-Co-impregnation method, CP-Coprecipitation method, MS-Molten salt method, MI-Microwave impregnation method, OAmIP-Oleylamine assisted impregnation method, SG-Sol-gel method; $y$-Yield of the product (\%), s-Selectivity of the product (\%), c-Concentration of the product (\%), $\mathrm{n}-$ Numbers of moles (mol) 
Table 4. The physicochemical and catalytic characterization of the catalytic systems used in the OSR of LNG reaction.

\begin{tabular}{|c|c|c|c|c|c|c|c|c|c|c|c|c|c|c|c|}
\hline Catalyst & $\begin{array}{l}\text { Preparation } \\
\text { Method }\end{array}$ & $\begin{array}{l}\mathrm{S}_{\mathrm{BET}} \\
{\left[\mathrm{m}^{2} / \mathrm{g}\right]}\end{array}$ & $\begin{array}{l}\text { Reduction } \\
\text { of } \mathrm{NiO}[\%]^{*}\end{array}$ & $\begin{array}{c}\text { Active Metal } \\
\text { dispersion } \\
{[\%]}\end{array}$ & $\begin{array}{c}\text { Metal } \\
\text { Particle Size } \\
{[\mathrm{nm}]}\end{array}$ & $\begin{array}{l}\mathrm{T}_{\mathrm{OSR}} \\
{\left[{ }^{\circ} \mathrm{C}\right]}\end{array}$ & $\begin{array}{c}\text { Catalyst } \\
\text { Weight } \\
\text { [g] }\end{array}$ & $\begin{array}{c}\mathrm{CH}_{4} \\
\text { Conv. } \\
{[\%]}\end{array}$ & $\begin{array}{c}\mathrm{C}_{2} \mathrm{H}_{6} \\
\text { Conv. } \\
{[\%]}\end{array}$ & $\begin{array}{c}\mathrm{C}_{3} \mathrm{H}_{8} \\
\text { Conv. } \\
{[\%]}\end{array}$ & $\begin{array}{c}\mathrm{C}_{4} \mathrm{H}_{10} \\
\text { Conv. } \\
{[\%]}\end{array}$ & $\mathbf{H}_{2}$ & $\mathrm{CO}$ & $\mathrm{CO}_{2}$ & $\begin{array}{r}\mathrm{H}_{2} \\
/ \mathrm{CO}\end{array}$ \\
\hline $\mathrm{Ni}(20) / \mathrm{ZrO}_{2}[135]$ & IP & 77 & 80 & - & $35^{* * *}$ & 700 & 0.2 & 98 & 100 & 100 & 100 & $57^{y}$ & $87^{s}$ & $13^{s}$ & 2.0 \\
\hline $\begin{array}{c}\mathrm{Ni}(20) / \mathrm{CeO}_{2}(5)-\mathrm{ZrO}_{2} \\
{[135]}\end{array}$ & IP & 79 & 60 & - & $22^{* * *}$ & 700 & 0.2 & 96 & 100 & 100 & 100 & $60 \mathrm{y}$ & $85^{\mathrm{s}}$ & $15^{\mathrm{s}}$ & 2.1 \\
\hline $\begin{array}{c}\mathrm{Ni}(20) / \mathrm{La}_{2} \mathrm{O}_{3}(5)-\mathrm{ZrO}_{2} \\
{[135]}\end{array}$ & IP & 74 & 99 & - & $41^{* * *}$ & 700 & 0.2 & 94 & 100 & 100 & 100 & $61^{y}$ & $86^{\mathrm{s}}$ & $14^{\mathrm{s}}$ & 2.2 \\
\hline $\begin{array}{c}\mathrm{Ag}(1)-\mathrm{Ni}(20) / \mathrm{ZrO}_{2} \\
{[137]}\end{array}$ & SIP & 69 & 88 & - & - & 700 & 0.2 & 72 & 100 & 100 & 100 & $59 \mathrm{y}$ & $64^{\mathrm{s}}$ & $36^{\mathrm{s}}$ & 3.2 \\
\hline
\end{tabular}

${ }^{*}$ based on TPR- $\mathrm{H}_{2}$ measurement; ** based on Specific Surface Area $\left(\mathrm{S}_{\mathrm{BET}}\right)$ measurement; ${ }^{* * *}$ based on XRD measurement; ${ }^{* * * *}$ based on TEM observation; a-Estimated from equation $\frac{0.971}{\text { dispersion }} \times 100$ (the particle size of noble metals atoms is the same as the nickel atom because of very small amount of noble metals); $\mathrm{b}-$ Based on $\mathrm{H}_{2}$-pulse chemisorption measurements; IP-Impregnation method, SIP-Subsequent impregnation method, CIP-Co-impregnation method, CP-Coprecipitation method, MS-Molten salt method, MI-Microwave impregnation method, OAmIP-Oleylamine assisted impregnation method, SG-Sol-gel method; y-Yield of the product (\%), s-Selectivity of the product (\%), c-Concentration of the product (\%), $\mathrm{n}$-Numbers of moles (mol). 


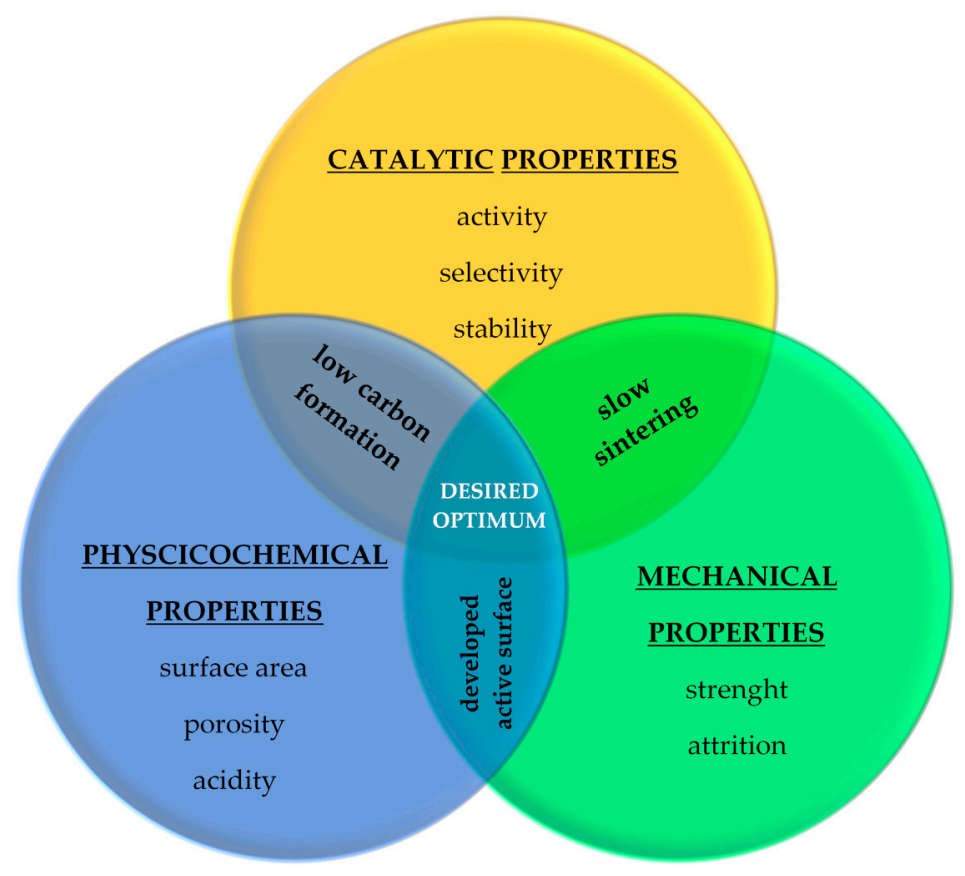

Figure 8. The catalyst design concept.

\section{Conclusions and Outlook}

The role of the environmental protection and the associated use of renewable raw materials for energy production is currently underlined. This fact has intensified research related to the use of alternative energy sources. According to the literature data presented in this review, we conclude that the selection of the catalytic material for the oxy - steam reforming process is not clear task and selected catalyst should be characterized by the high activity and stability and should be able to limit the formation of carbon deposit on its surface. In this work, we presented latest data concerning the monoand bimetallic systems used in the reforming processes of methane and LNG. With particular emphasis on the description of the nickel catalysts used in the reforming of methane and LNG processes.

Author Contributions: The work was designed and presented by M.M., M.I.S. and P.M. All authors have read and agreed to the published version of the manuscript.

Funding: The work was funded by the National Science Centre within the "OPUS" Programme, Poland (Grant No. 2018/29/B/ST8/01317).

Conflicts of Interest: The authors declare no conflicts of interest.

\section{References}

1. Madej-Lachowska, M.; Kulawska, M.; Hamryszak, L. Kinetic studies on steam reforming of methanol over $\mathrm{Cu} / \mathrm{Zn} / \mathrm{Zr} / \mathrm{Ce} / \mathrm{Cr}$ catalyst. Przem. Chem. 2016, 95, 2281-2284. [CrossRef]

2. Deczyński, J.; Żółtowski, B. WodÓr Jako Paliwo Alternatywne Do Zasilania SilnikÓw Ze Spalaniem WewnEtrznym. Studia Mater. Pol. Stowarzyszenia Zarz. Wiedza/Stud. Proc. Pol. Assoc. Knowl. Manag. 2014, 69, $18-31$.

3. Dutta, S. A review on production, storage of hydrogen and its utilization as an energy resource. J. Ind. Eng. Chem. 2014, 20, 1148-1156. [CrossRef]

4. Mierczynski, P. Comparative Studies of Bimetallic $\mathrm{Ru}-\mathrm{Cu}, \mathrm{Rh}-\mathrm{Cu}, \mathrm{Ag}-\mathrm{Cu}, \mathrm{Ir}-\mathrm{Cu}$ Catalysts Supported on ZnO-Al2O3, ZrO2-Al2O3 Systems. Catal. Lett. 2016, 146, 1825-1837. [CrossRef]

5. Mierczynski, P.; Mierczynska, A.; Maniukiewicz, W.; Maniecki, T.P.; Vasilev, K. MWCNTs as a catalyst in oxy-steam reforming of methanol. Rsc Adv. 2016, 6, 81408-81413. [CrossRef] 
6. Mierczynski, P.; Ciesielski, R.; Kedziora, A.; Nowosielska, M.; Kubicki, J.; Maniukiewicz, W.; Czylkowska, A.; Maniecki, T.P. Monometallic copper catalysts supported on multi-walled carbon nanotubes for the oxy-steam reforming of methanol. React. Kinet. Mech. Catal. 2016, 117, 675-691. [CrossRef]

7. Appleby, A.J. Fuel cell technology: Status and future prospects. Energy 1996, 21, 521-653. [CrossRef]

8. Bae, J.; Lee, S.; Kim, S.; Oh, J.; Choi, S.; Bae, M.; Kang, I.; Katikaneni, S.P. Liquid fuel processing for hydrogen production: A review. Int. J. Hydrog. Energy 2016, 41, 19990-20022. [CrossRef]

9. Bi, L.; Boulfrad, S.; Traversa, E. Reversible solid oxide fuel cells (R-SOFCs) with chemically stable proton-conducting oxides. Solid State Ion. 2015, 275, 101-105. [CrossRef]

10. Cheekatamarla, P.K.; Finnerty, C.M. Reforming catalysts for hydrogen generation in fuel cell applications. J. Power Sources 2006, 160, 490-499. [CrossRef]

11. ElMekawy, A.; Hegab, H.M.; Vanbroekhoven, K.; Pant, D. Techno-productive potential of photosynthetic microbial fuel cells through different configurations. Renew. Sustain. Energy Rev. 2014, 39, 617-627. [CrossRef]

12. Eveloy, V. Numerical analysis of an internal methane reforming solid oxide fuel cell with fuel recycling. Appl. Energy 2012, 93, 107-115. [CrossRef]

13. Fu, X.-Z.; Melnik, J.; Low, Q.-X.; Luo, J.-L.; Chuang, K.T.; Sanger, A.R.; Yang, Q.-M. Surface modified Ni foam as current collector for syngas solid oxide fuel cells with perovskite anode catalyst. Int. J. Hydrog. Energy 2010, 35, 11180-11187. [CrossRef]

14. Frusteri, F.; Freni, S. Bio-ethanol, a suitable fuel to produce hydrogen for a molten carbonate fuel cell. J. Power Sources 2007, 173, 200-209. [CrossRef]

15. Geissler, K.; Newson, E.; Vogel, F.; Truong, T.-B.; Hottinger, P.; Wokaun, A. Autothermal methanol reforming for hydrogen production in fuel cell applications. Phys. Chem. Chem. Phys. 2001, 3, 289-293. [CrossRef]

16. Wang, W.; Su, C.; Zheng, T.; Liao, M.; Shao, Z. Nickel zirconia cerate cermet for catalytic partial oxidation of ethanol in a solid oxide fuel cell system. Int. J. Hydrog. Energy 2012, 37, 8603-8612. [CrossRef]

17. Lindström, B.; Pettersson, L.J. Hydrogen generation by steam reforming of methanol over copper-based catalysts for fuel cell applications. Int. J. Hydrog. Energy 2001, 26, 923-933. [CrossRef]

18. Rosen, M.A. Thermodynamic investigation and comparison of selected production processes for hydrogen and hydrogen-derived fuels. Energy 1996, 21, 1079-1094. [CrossRef]

19. Demusiak, G. Otrzymywanie paliwa wodorowego metodą reformowania gazu ziemnego dla ogniw paliwowych małej mocy. Naft. Gaz 2012, 68, 661-673.

20. Muritala, I.K.; Guban, D.; Roeb, M.; Sattler, C. High temperature production of hydrogen: Assessment of non-renewable resources technologies and emerging trends. Int. J. Hydrog. Energy 2019. [CrossRef]

21. Dincer, I.; Zamfirescu, C. Sustainable hydrogen production options and the role of IAHE. Int. J. Hydrog. Energy 2012, 37, 16266-16286. [CrossRef]

22. Park, S.; Yoo, J.; Han, S.J.; Song, J.H.; Lee, E.J.; Song, I.K. Steam reforming of liquefied natural gas (LNG) for hydrogen production over nickel-boron-alumina xerogel catalyst. Int. J. Hydrog. Energy 2017, 42, 15096-15106. [CrossRef]

23. Ma, L.; Geng, J.; Li, W.; Liu, P.; Li, Z. The development of natural gas as an automotive fuel in China. Energy Policy 2013, 62, 531-539. [CrossRef]

24. Bernatík, A.; Senovsky, P.; Pitt, M. LNG as a potential alternative fuel—Safety and security of storage facilities. J. Loss Prev. Process Ind. 2011, 24, 19-24. [CrossRef]

25. Osorio-Tejada, J.L.; Llera-Sastresa, E.; Scarpellini, S. LNG: An alternative fuel for road freight transport in Europe. In Sustainable Development; Wessex Institute of Technology: Southampton, UK, 2015; pp. 235-246. [CrossRef]

26. Atsonios, K.; Samlis, C.; Manou, K.; Nikolopoulos, A.; Sfetsioris, K.; Mitsotakis, A.; Grammelis, P. Technical assessment of LNG based polygeneration systems for non-interconnected island cases using SOFC. Int. J. Hydrog. Energy 2020. [CrossRef]

27. Strantzali, E.; Aravossis, K.; Livanos, G.A. Evaluation of future sustainable electricity generation alternatives: The case of a Greek island. Renew. Sustain. Energy Rev. 2017, 76, 775-787. [CrossRef]

28. Bang, Y.; Park, S.; Han, S.J.; Yoo, J.; Song, J.H.; Choi, J.H.; Kang, K.H.; Song, I.K. Hydrogen production by steam reforming of liquefied natural gas (LNG) over mesoporous Ni/Al2O3 catalyst prepared by an EDTA-assisted impregnation method. Appl. Catal. B Environ. 2016, 180, 179-188. [CrossRef] 
29. Yoo, J.; Bang, Y.; Han, S.J.; Kang, T.H.; Lee, J.; Song, I.K. Hydrogen production by steam reforming of liquefied natural gas (LNG) over mesoporous alkaline earth metal-promoted nickel-alumina xerogel catalysts. J. Mol. Catal. A Chem. 2013, 380, 28-33. [CrossRef]

30. Seo, J.G.; Youn, M.H.; Song, I.K. Hydrogen production by steam reforming of LNG over Ni/Al2O3-ZrO2 catalysts: Effect of Al2O3-ZrO2 supports prepared by a grafting method. J. Mol. Catal. A Chem. 2007, 268, 9-14. [CrossRef]

31. Balat, M. Potential importance of hydrogen as a future solution to environmental and transportation problems. Int. J. Hydrog. Energy 2008, 33, 4013-4029. [CrossRef]

32. Barbir, F. PEM Fuel Cells. In Fuel Cell Technology: Reaching Towards Commercialization; Sammes, N., Ed.; Springer: London, UK, 2006; pp. 27-51.

33. Park, S.; Bang, Y.; Han, S.J.; Yoo, J.; Song, J.H.; Song, J.C.; Lee, J.; Song, I.K. Hydrogen production by steam reforming of liquefied natural gas (LNG) over mesoporous nickel-iron-alumina catalyst. Int. J. Hydrog. Energy 2015, 40, 5869-5877. [CrossRef]

34. Yang, X.; Zhao, H.; Hou, Q. Proposal and thermodynamic performance study of a novel LNG-fueled SOFC-HAT-CCHP system with near-zero CO2 emissions. Int. J. Hydrog. Energy 2020. [CrossRef]

35. Bang, Y.; Seo, J.G.; Song, I.K. Hydrogen production by steam reforming of liquefied natural gas (LNG) over mesoporous Ni-La-Al2O3 aerogel catalysts: Effect of La content. Int. J. Hydrog. Energy 2011, 36, 8307-8315. [CrossRef]

36. Mukainakano, Y.; Yoshida, K.; Kado, S.; Okumura, K.; Kunimori, K.; Tomishige, K. Catalytic performance and characterization of $\mathrm{Pt}-\mathrm{Ni}$ bimetallic catalysts for oxidative steam reforming of methane. Chem. Eng. Sci. 2008, 63, 4891-4901. [CrossRef]

37. Nurunnabi, M.; Mukainakano, Y.; Kado, S.; Miyao, T.; Naito, S.; Okumura, K.; Kunimori, K.; Tomishige, K. Catalytic performance and characterization of $\mathrm{Pd} / \mathrm{Ni}_{0.2} \mathrm{Mg}_{0.8} \mathrm{Al}_{2} \mathrm{O}_{4}$ in oxidative steam reforming of methane under atmospheric and pressurized conditions. Appl. Catal. A Gen. 2007, 325, 154-162. [CrossRef]

38. Hosseini, S.M.S.; Hashemipour rafsanjani, H.; Talebizadeh, A.R. Methane oxy-steam reforming over a highly efficient $\mathrm{Ni} / \mathrm{Al}_{2} \mathrm{O}_{3}$ nanocatalyst prepared by microwave-assisted impregnation method. Iran. J. Chem. Eng. (Ijche) 2017, 14, 3-16.

39. Tomishige, K. Oxidative Steam Reforming of Methane over Ni Catalysts Modified with Noble Metals. J. Jpn. Pet. Inst. 2007, 50, 287-298. [CrossRef]

40. Roh, H.-S.; Jun, K.-W.; Dong, W.-S.; Park, S.-E.; Baek, Y.-S. Highly stable Ni catalyst supported on Ce-ZrO 2 for oxy-steam reforming of methane. Catal. Lett. 2001, 74, 31-36. [CrossRef]

41. Bang, Y.; Han, S.J.; Yoo, J.; Choi, J.H.; Lee, J.K.; Song, J.H.; Lee, J.; Song, I.K. Hydrogen production by steam reforming of simulated liquefied natural gas (LNG) over nickel catalyst supported on mesoporous phosphorus-modified alumina xerogel. Appl. Catal. B Environ. 2014, 148, 269-280. [CrossRef]

42. Bang, Y.; Park, S.; Han, S.J.; Yoo, J.; Choi, J.H.; Kang, T.H.; Lee, J.; Song, I.K. Hydrogen Production by Steam Reforming of Liquefied Natural Gas (LNG) Over Nickel-Phosphorus-Alumina Xerogel Catalyst Prepared by a Carbon-Templating Epoxide-Driven Sol-Gel Method. J. Nanosci. Nanotechnol. 2016, 16, 4605-4611. [CrossRef]

43. Pino, L.; Recupero, V.; Beninati, S.; Shukla, A.; Hegde, M.; Bera, P. Catalytic partial-oxidation of methane on a ceria-supported platinum catalyst for application in fuel cell electric vehicles. Appl. Catal. A Gen. 2002, 225, 63-75. [CrossRef]

44. Boudjeloud, M.; Boulahouache, A.; Rabia, C.; Salhi, N. La-doped supported Ni catalysts for steam reforming of methane. Int. J. Hydrog. Energy 2019, 44, 9906-9913. [CrossRef]

45. Al-Ubaid, A.; Wolf, E.E. Steam reforming of methane on reduced non-stoichiometric nickel aluminate catalysts. Appl. Catal. 1988, 40, 73-85. [CrossRef]

46. Laosiripojana, N.; Assabumrungrat, S. Methane steam reforming over $\mathrm{Ni} / \mathrm{Ce}-\mathrm{ZrO}_{2}$ catalyst: Influences of $\mathrm{Ce}-\mathrm{ZrO}_{2}$ support on reactivity, resistance toward carbon formation, and intrinsic reaction kinetics. Appl. Catal. A Gen. 2005, 290, 200-211. [CrossRef]

47. de Lima, S.M.; da Cruz, I.O.; Jacobs, G.; Davis, B.H.; Mattos, L.V.; Noronha, F.B. Steam reforming, partial oxidation, and oxidative steam reforming of ethanol over $\mathrm{Pt} / \mathrm{CeZrO}$ catalyst. J. Catal. 2008, 257, 356-368. [CrossRef]

48. Yang, X.; Da, J.; Yu, H.; Wang, H. Characterization and performance evaluation of Ni-based catalysts with Ce promoter for methane and hydrocarbons steam reforming process. Fuel 2016, 179, 353-361. [CrossRef] 
49. Asencios, Y.J.O.; Nascente, P.A.P.; Assaf, E.M. Partial oxidation of methane on $\mathrm{NiO}-\mathrm{MgO}-\mathrm{ZrO}_{2}$ catalysts. Fuel 2012, 97, 630-637. [CrossRef]

50. Eriksson, S.; Rojas, S.; Boutonnet, M.; Fierro, J.L.G. Effect of Ce-doping on $\mathrm{Rh} / \mathrm{ZrO}_{2}$ catalysts for partial oxidation of methane. Appl. Catal. A Gen. 2007, 326, 8-16. [CrossRef]

51. Dong, W.-S.; Jun, K.-W.; Roh, H.-S.; Liu, Z.-W.; Park, S.-E. Comparative Study on Partial Oxidation of Methane over Ni/ZrO2, Ni/CeO2 and Ni/Ce-ZrO2 Catalysts. Catal. Lett. 2002, 78, 215-222. [CrossRef]

52. Lødeng, R.; Bjørgum, E.; Enger, B.C.; Eilertsen, J.L.; Holmen, A.; Krogh, B.; Rønnekleiv, M.; Rytter, E. Catalytic partial oxidation of $\mathrm{CH} 4$ to $\mathrm{H} 2$ over cobalt catalysts at moderate temperatures. Appl. Catal. A Gen. 2007, 333, 11-23. [CrossRef]

53. Wang, W.; Su, C.; Ran, R.; Park, H.J.; Kwak, C.; Shao, Z. Physically mixed LiLaNi- $\mathrm{Al}_{2} \mathrm{O}_{3}$ and copper as conductive anode catalysts in a solid oxide fuel cell for methane internal reforming and partial oxidation. Int. J. Hydrog. Energy 2011, 36, 5632-5643. [CrossRef]

54. Özkara-Aydınoğlu, S.; Özensoy, E.; Aksoylu, A.E. The effect of impregnation strategy on methane dry reforming activity of Ce promoted $\mathrm{Pt} / \mathrm{ZrO}_{2}$. Int. J. Hydrog. Energy 2009, 34, 9711-9722. [CrossRef]

55. Bachiller-Baeza, B.; Mateos-Pedrero, C.; Soria, M.A.; Guerrero-Ruiz, A.; Rodemerck, U.; Rodríguez-Ramos, I. Transient studies of low-temperature dry reforming of methane over $\mathrm{Ni}-\mathrm{CaO} / \mathrm{ZrO}_{2}-\mathrm{La}_{2} \mathrm{O}_{3}$. Appl. Catal. B Environ. 2013, 129, 450-459. [CrossRef]

56. Luisetto, I.; Tuti, S.; Battocchio, C.; Lo Mastro, S.; Sodo, A. Ni/CeO $\mathrm{C}_{2}-\mathrm{Al}_{2} \mathrm{O}_{3}$ catalysts for the dry reforming of methane: The effect of $\mathrm{CeAlO}_{3}$ content and nickel crystallite size on catalytic activity and coke resistance. Appl. Catal. A Gen. 2015, 500, 12-22. [CrossRef]

57. Hassani Rad, S.J.; Haghighi, M.; Alizadeh Eslami, A.; Rahmani, F.; Rahemi, N. Sol-gel vs. impregnation preparation of $\mathrm{MgO}$ and $\mathrm{CeO}_{2}$ doped $\mathrm{Ni} / \mathrm{Al}_{2} \mathrm{O}_{3}$ nanocatalysts used in dry reforming of methane: Effect of process conditions, synthesis method and support composition. Int. J. Hydrog. Energy 2016, 41, 5335-5350. [CrossRef]

58. Hou, Z.; Yokota, O.; Tanaka, T.; Yashima, T. Characterization of Ca-promoted Ni/ $\alpha-\mathrm{Al}_{2} \mathrm{O}_{3}$ catalyst for $\mathrm{CH}_{4}$ reforming with $\mathrm{CO}_{2}$. Appl. Catal. A Gen. 2003, 253, 381-387. [CrossRef]

59. Laosiripojana, N.; Assabumrungrat, S. Catalytic dry reforming of methane over high surface area ceria. Appl. Catal. B Environ. 2005, 60, 107-116. [CrossRef]

60. Kambolis, A.; Matralis, H.; Trovarelli, A.; Papadopoulou, C. Ni/CeO $-\mathrm{ZrO}_{2}$ catalysts for the dry reforming of methane. Appl. Catal. A Gen. 2010, 377, 16-26. [CrossRef]

61. Wu, H.; Pantaleo, G.; La Parola, V.; Venezia, A.M.; Collard, X.; Aprile, C.; Liotta, L.F. Bi- and trimetallic Ni catalysts over $\mathrm{Al}_{2} \mathrm{O}_{3}$ and $\mathrm{Al}_{2} \mathrm{O}_{3}-\mathrm{MOx}(\mathrm{M}=\mathrm{Ce}$ or $\mathrm{Mg}$ ) oxides for methane dry reforming: $\mathrm{Au}$ and $\mathrm{Pt}$ additive effects. Appl. Catal. B Environ. 2014, 156-157, 350-361. [CrossRef]

62. Vella, L.D.; Specchia, S. Alumina-supported nickel catalysts for catalytic partial oxidation of methane in short-contact time reactors. Catal. Today 2011, 176, 340-346. [CrossRef]

63. Vella, L.D.; Villoria, J.A.; Specchia, S.; Mota, N.; Fierro, J.L.G.; Specchia, V. Catalytic partial oxidation of $\mathrm{CH}_{4}$ with nickel-lanthanum-based catalysts. Catal. Today 2011, 171, 84-96. [CrossRef]

64. Maniecki, T.P.; Bawolak, K.; Gebauer, D.; Mierczynski, P.; Jozwiak, W.K. Catalytic activity and physicochemical properties of $\mathrm{Ni}-\mathrm{Au} / \mathrm{Al}_{3} \mathrm{CrO}_{6}$ system for partial oxidation of methane to synthesis gas. Kinet. Catal. 2009, 50, 138-144. [CrossRef]

65. Maniecki, T.P.; Bawolak, K.; Mierczyński, P.; Jozwiak, W.K. Development of Stable and Highly Active Bimetallic Ni-Au Catalysts Supported on Binary Oxides $\mathrm{CrAl}_{3} \mathrm{O}_{6}$ for POM Reaction. Catal. Lett. 2008, 128, 401. [CrossRef]

66. Maniecki, T.; Bawolak, K.; Mierczynski, P.; Kaczorowski, P.; Jozwiak, W. The effect of the nature of the support on catalytic properties of ruthenium supported catalysts in partial oxidation of methane to syn-gas. Kinet. Catal. 2011, 52, 711-715. [CrossRef]

67. Pańczyk, M.; Borowiecki, T. Otrzymywanie i zastosowanie gazu syntezowego. W: Adsorbenty i katalizatory: Wybrane technologie a środowisko. Red. J. Univ. Rzesz. 2012, 275-287.

68. Wiącek, D. Wodór jako paliwo przyszłości. Autobusy Tech. Eksploat. Syst. Transp. 2011, 12, 446-452.

69. Pino, L.; Vita, A.; Cordaro, M.; Recupero, V.; Hegde, M.S. A comparative study of $\mathrm{Pt} / \mathrm{CeO}_{2}$ catalysts for catalytic partial oxidation of methane to syngas for application in fuel cell electric vehicles. Appl. Catal. A Gen. 2003, 243, 135-146. [CrossRef] 
70. Christian Enger, B.; Lødeng, R.; Holmen, A. A review of catalytic partial oxidation of methane to synthesis gas with emphasis on reaction mechanisms over transition metal catalysts. Appl. Catal. A Gen. 2008, 346, 1-27. [CrossRef]

71. Rostrup-Nielsen, J.R. Catalytic Steam Reforming. In Catalysis: Science and Technology Volume 5; Anderson, J.R., Boudart, M., Eds.; Springer Berlin Heidelberg: Berlin/Heidelberg, Germany, 1984; pp. 1-117.

72. Sadek, R.; Chalupka, K.A.; Mierczynski, P.; Rynkowski, J.; Millot, Y.; Valentin, L.; Casale, S.; Dzwigaj, S. Fischer-Tropsch reaction on Co-containing microporous and mesoporous Beta zeolite catalysts: The effect of porous size and acidity. Catal. Today 2019. [CrossRef]

73. Sadek, R.; Chalupka, K.A.; Mierczynski, P.; Rynkowski, J.; Gurgul, J.; Dzwigaj, S. Cobalt based catalysts supported on two kinds of beta zeolite for application in fischer-tropsch synthesis. Catalysts 2019, 9, 497. [CrossRef]

74. Mierczynski, P.; Dawid, B.; Maniukiewicz, W.; Mosinska, M.; Zakrzewski, M.; Ciesielski, R.; Kedziora, A.; Dubkov, S.; Gromov, D.; Rogowski, J.; et al. Fischer-Tropsch synthesis over various $\mathrm{Fe} / \mathrm{Al}_{2} \mathrm{O}_{3}-\mathrm{Cr}_{2} \mathrm{O}_{3}$ catalysts. React. Kinet. Mech. Catal. 2018, 124, 545-561. [CrossRef]

75. Chalupka, K.A.; Maniukiewicz, W.; Mierczynski, P.; Maniecki, T.; Rynkowski, J.; Dzwigaj, S. The catalytic activity of Fe-containing SiBEA zeolites in Fischer-Tropsch synthesis. Catal. Today 2015, 257 Pt 1, 117-121. [CrossRef]

76. Maniecki, T.; Stadnichenko, A.; Maniukiewicz, W.; Bawolak, K.; Mierczynski, P.; Boronin, A.; Jozwiak, W. An active phase transformation on surface of $\mathrm{Ni}-\mathrm{Au} / \mathrm{Al}_{2} \mathrm{O}_{3}$ catalyst during partial oxidation of methane to synthesis gas. Kinet. Catal. 2010, 51, 573-578. [CrossRef]

77. Fisher, I.A.; Bell, A.T. In Situ Infrared Study of Methanol Synthesis from $\mathrm{H}_{2} / \mathrm{CO}$ over $\mathrm{Cu} / \mathrm{SiO}{ }_{2}$ and $\mathrm{Cu} / \mathrm{ZrO}_{2} / \mathrm{SiO}_{2}$. J. Catal. 1998, 178, 153-173. [CrossRef]

78. Abbaslou, R.M.M.; Tavassoli, A.; Soltan, J.; Dalai, A.K. Iron catalysts supported on carbon nanotubes for Fischer-Tropsch synthesis: Effect of catalytic site position. Appl. Catal. A Gen. 2009, 367, 47-52. [CrossRef]

79. Albuquerque, J.S.; Costa, F.O.; Barbosa, B.V.S. Fischer-Tropsch Synthesis: Analysis of Products by Anderson-Schulz-Flory Distribution Using Promoted Cobalt Catalyst. Catal. Lett. 2019, 149, 831-839. [CrossRef]

80. Bahome, M.C.; Jewell, L.L.; Hildebrandt, D.; Glasser, D.; Coville, N.J. Fischer-Tropsch synthesis over iron catalysts supported on carbon nanotubes. Appl. Catal. A Gen. 2005, 287, 60-67. [CrossRef]

81. Niemantsverdriet, J.W.; Van der Kraan, A.M.; Van Dijk, W.L.; Van der Baan, H.S. Behavior of metallic iron catalysts during Fischer-Tropsch synthesis studied with Moessbauer spectroscopy, x-ray diffraction, carbon content determination, and reaction kinetic measurements. J. Phys. Chem. 1980, 84, 3363-3370. [CrossRef]

82. Davis, B.H. Fischer-Tropsch Synthesis: Reaction mechanisms for iron catalysts. Catal. Today 2009, 141, 25-33. [CrossRef]

83. Iablokov, V.; Kruse, N. Discovery of a Fischer-Tropsch Hybrid Reaction: Hydrogenation of Methylformate to Long-Chain Hydrocarbons with Anderson-Schulz-Flory Chain Length Distribution. ChemCatChem 2019, 11, 1200-1204. [CrossRef]

84. Intergovernmental Panel on Climate Change. Climate Change 2014: Mitigation of Climate Change: Working Group III Contribution to the IPCC Fifth Assessment Report; Cambridge University Press: Cambridge, UK, 2015.

85. Aramouni, N.A.K.; Touma, J.G.; Tarboush, B.A.; Zeaiter, J.; Ahmad, M.N. Catalyst design for dry reforming of methane: Analysis review. Renew. Sustain. Energy Rev. 2018, 82, 2570-2585. [CrossRef]

86. Ginsburg, J.M.; Piña, J.; El Solh, T.; de Lasa, H.I. Coke Formation over a Nickel Catalyst under Methane Dry Reforming Conditions: Thermodynamic and Kinetic Models. Ind. Eng. Chem. Res. 2005, 44, 4846-4854. [CrossRef]

87. Bradford, M.C.J.; Vannice, M.A. Catalytic reforming of methane with carbon dioxide over nickel catalysts I. Catalyst characterization and activity. Appl. Catal. A Gen. 1996, 142, 73-96. [CrossRef]

88. Pakhare, D.; Spivey, J. A review of dry $\left(\mathrm{CO}_{2}\right)$ reforming of methane over noble metal catalysts. Chem. Soc. Rev. 2014, 43, 7813-7837. [CrossRef]

89. Dong, W.-S.; Roh, H.-S.; Liu, Z.-W.; Jun, K.-W.; Park, S.-E. Hydrogen Production from Methane Reforming Reactions over Ni/MgO Catalyst. Bull. Korean Chem. Soc. 2001, 22, 1323-1327.

90. Peela, N.R.; Kunzru, D. Oxidative steam reforming of ethanol over Rh based catalysts in a micro-channel reactor. Int. J. Hydrog. Energy 2011, 36, 3384-3396. [CrossRef] 
91. Mierczynski, P.; Ciesielski, R.; Kedziora, A.; Zaborowski, M.; Maniukiewicz, W.; Nowosielska, M.; Szynkowska, M.I.; Maniecki, T.P. Novel Pd-Cu/ZnAl ${ }_{2} \mathrm{O}_{4}-\mathrm{ZrO}_{2}$ Catalysts for Methanol Synthesis. Catal. Lett. 2014, 144, 723-735. [CrossRef]

92. Bell, A.T. Molecular Design of Highly Active Methanol Synthesis Catalysts. In Studies in Surface Science and Catalysis; Iglesia, E., Spivey, J.J., Fleisch, T.H., Eds.; Elsevier: Amsterdam, The Netherlands, 2001; Volume 136, pp. 13-19.

93. Fan, L.; Fujimoto, K. Reaction Mechanism of Methanol Synthesis from Carbon Dioxide and Hydrogen on Ceria-Supported Palladium Catalysts with SMSI Effect. J. Catal. 1997, 172, 238-242. [CrossRef]

94. Larrubia Vargas, M.A.; Busca, G.; Costantino, U.; Marmottini, F.; Montanari, T.; Patrono, P.; Pinzari, F.; Ramis, G. An IR study of methanol steam reforming over ex-hydrotalcite $\mathrm{Cu}-\mathrm{Zn}-\mathrm{Al}$ catalysts. J. Mol. Catal. A Chem. 2007, 266, 188-197. [CrossRef]

95. Ma, Y.; Ge, Q.; Li, W.; Xu, H. Methanol synthesis from sulfur-containing syngas over $\mathrm{Pd} / \mathrm{CeO}_{2}$ catalyst. Appl. Catal. B Environ. 2009, 90, 99-104. [CrossRef]

96. Pasupulety, N.; Driss, H.; Alhamed, Y.A.; Alzahrani, A.A.; Daous, M.A.; Petrov, L. Studies on Au/Cu-Zn-Al catalyst for methanol synthesis from $\mathrm{CO}_{2}$. Appl. Catal. A Gen. 2015, 504, 308-318. [CrossRef]

97. Xu, J.; Su, X.; Liu, X.; Pan, X.; Pei, G.; Huang, Y.; Wang, X.; Zhang, T.; Geng, H. Methanol synthesis from $\mathrm{CO}_{2}$ and $\mathrm{H}_{2}$ over $\mathrm{Pd} / \mathrm{ZnO} / \mathrm{Al}_{2} \mathrm{O}_{3}$ : Catalyst structure dependence of methanol selectivity. Appl. Catal. A Gen. 2016, 514, 51-59. [CrossRef]

98. Jens, R.-N. Concepts in Syngas Manufacture; World Scientific: Haldor Topsoe A/S, Denmark, 2011; Volume 10. [CrossRef]

99. Makvandi, S.; Alavi, S. COx free hydrogen production by catalytic decomposition of methane over porous $\mathrm{Ni} / \mathrm{Al} 2 \mathrm{O} 3$ catalysts. Iran. J. Chem. Eng. 2011, 8, 24-33.

100. Sharaf, O.Z.; Orhan, M.F. An overview of fuel cell technology: Fundamentals and applications. Renew. Sustain. Energy Rev. 2014, 32, 810-853. [CrossRef]

101. Bobadilla, L.F.; Palma, S.; Ivanova, S.; Domínguez, M.I.; Romero-Sarria, F.; Centeno, M.A.; Odriozola, J.A. Steam reforming of methanol over supported Ni and Ni-Sn nanoparticles. Int. J. Hydrog. Energy 2013, 38, 6646-6656. [CrossRef]

102. Kurzina, I.A.; Reshetnikov, S.I.; Karakchieva, N.I.; Kurina, L.N. Direct synthesis of dimethyl ether from synthesis gas: Experimental study and mathematical modeling. Chem. Eng. J. 2017, 329, 135-141. [CrossRef]

103. Dong, X.; Liang, X.-L.; Li, H.-Y.; Lin, G.-D.; Zhang, P.; Zhang, H.-B. Preparation and characterization of carbon nanotube-promoted $\mathrm{Co}-\mathrm{Cu}$ catalyst for higher alcohol synthesis from syngas. Catal. Today 2009, 147, 158-165. [CrossRef]

104. Zhang, M.-H.; Liu, Z.-M.; Lin, G.-D.; Zhang, H.-B. Pd/CNT-promoted CuZrO $2 / \mathrm{HZSM-5}$ hybrid catalysts for direct synthesis of DME from $\mathrm{CO}_{2} / \mathrm{H}_{2}$. Appl. Catal. A Gen. 2013, 451, 28-35. [CrossRef]

105. Saravanan, K.; Ham, H.; Tsubaki, N.; Bae, J.W. Recent progress for direct synthesis of dimethyl ether from syngas on the heterogeneous bifunctional hybrid catalysts. Appl. Catal. B Environ. 2017, 217, 494-522. [CrossRef]

106. Mosinska, M.; Stępińska, N.; Maniukiewicz, W.; Rogowski, J.; Mierczynska-Vasilev, A.; Vasilev, K.; Szynkowska, M.I.; Mierczynski, P. Hydrogen Production on Cu-Ni Catalysts via the Oxy-Steam Reforming of Methanol. Catalysts 2020, 10, 273. [CrossRef]

107. Haynes, D.J.; Shekhawat, D. Chapter 6-Oxidative Steam Reforming. In Fuel Cells: Technologies for Fuel Processing; Shekhawat, D., Spivey, J.J., Berry, D.A., Eds.; Elsevier: Amsterdam, The Netherlands, 2011; pp. 129-190.

108. Rabenstein, G.; Hacker, V. Hydrogen for fuel cells from ethanol by steam-reforming, partial-oxidation and combined auto-thermal reforming: A thermodynamic analysis. J. Power Sources 2008, 185, 1293-1304. [CrossRef]

109. Neiva, A.; Gama, A. A study on the characteristics of the reforming of methane: A review. Braz. J. Pet Gas 2010, 4. [CrossRef]

110. Herrera Delgado, K.; Maier, L.; Tischer, S.; Zellner, A.; Stotz, H.; Deutschmann, O. Surface Reaction Kinetics of Steam- and $\mathrm{CO}_{2}$-Reforming as Well as Oxidation of Methane over Nickel-Based Catalysts. Catalysts 2015, 5, 871-904. [CrossRef] 
111. Li, B.; Maruyama, K.; Nurunnabi, M.; Kunimori, K.; Tomishige, K. Temperature profiles of alumina-supported noble metal catalysts in autothermal reforming of methane. Appl. Catal. A Gen. 2004, 275, 157-172. [CrossRef]

112. Pino, L.; Vita, A.; Cipitì, F.; Laganà, M.; Recupero, V. Performance of $\mathrm{Pt} / \mathrm{CeO}_{2}$ catalyst for propane oxidative steam reforming. Appl. Catal. A Gen. 2006, 306, 68-77. [CrossRef]

113. Ruiz, J.A.C.; Passos, F.B.; Bueno, J.M.C.; Souza-Aguiar, E.F.; Mattos, L.V.; Noronha, F.B. Syngas production by autothermal reforming of methane on supported platinum catalysts. Appl. Catal. A Gen. 2008, 334, 259-267. [CrossRef]

114. Souza, A.E.A.M.; Maciel, L.J.L.; Cavalcanti-Filho, V.O.; Filho, N.M.L.; Abreu, C.A.M. Kinetic-Operational Mechanism to Autothermal Reforming of Methane. Ind. Eng. Chem. Res. 2011, 50, 2585-2599. [CrossRef]

115. Li, B.; Li, H.; Weng, W.-Z.; Zhang, Q.; Huang, C.-J.; Wan, H.-L. Synthesis gas production from partial oxidation of methane over highly dispersed $\mathrm{Pd} / \mathrm{SiO}_{2}$ catalyst. Fuel 2013, 103, 1032-1038. [CrossRef]

116. Li, C.; Ying, W.; Cao, F.; Zhang, H.; Fang, D. Effects of Impregnation Solvents on Catalytic Performance of $\mathrm{Co}-\mathrm{Ru}-\mathrm{ZrO}_{2} / \gamma-\mathrm{Al}_{2} \mathrm{O}_{3}$ Catalyst for Fischer-Tropsch Synthesis. Pet. Sci. Technol. 2008, 26, 704-716. [CrossRef]

117. Negrier, F.; Marceau, É.; Che, M.; de Caro, D. Role of ethylenediamine in the preparation of alumina-supported $\mathrm{Ni}$ catalysts from $\left[\mathrm{Ni}(\mathrm{en})_{2}\left(\mathrm{H}_{2} \mathrm{O}\right)_{2}\right]\left(\mathrm{NO}_{3}\right)_{2}$ : From solution properties to nickel particles. Comptes Rendus Chim. 2003, 6, 231-240. [CrossRef]

118. Bentaleb, F.; Che, M.; Dubreuil, A.-C.; Thomazeau, C.; Marceau, E. Influence of organic additives on the properties of impregnation solutions and on nickel oxide particle size for $\mathrm{Ni} / \mathrm{Al}_{2} \mathrm{O}_{3}$ catalysts. Catal. Today 2014, 235, 250-255. [CrossRef]

119. Boukha, Z.; Jiménez-González, C.; de Rivas, B.; González-Velasco, J.R.; Gutiérrez-Ortiz, J.I.; López-Fonseca, R. Synthesis, characterisation and performance evaluation of spinel-derived $\mathrm{Ni} / \mathrm{Al}_{2} \mathrm{O}_{3}$ catalysts for various methane reforming reactions. Appl. Catal. B Environ. 2014, 158, 190-201. [CrossRef]

120. Morales-Cano, F.; Lundegaard, L.F.; Tiruvalam, R.R.; Falsig, H.; Skjøth-Rasmussen, M.S. Improving the sintering resistance of $\mathrm{Ni} / \mathrm{Al}_{2} \mathrm{O}_{3}$ steam-reforming catalysts by promotion with noble metals. Appl. Catal. A Gen. 2015, 498, 117-125. [CrossRef]

121. Moradi, P.; Parvari, M. Preparation of Lanthanum-Nickel-Aluminium Perovskite Systems And Their Application In Methane-Reforming Reactions. Iran. J. Chem. Eng. 2006, 3, $29-43$.

122. Pérez-Hernández, R.; Mondragón-Galicia, G.; Allende Maravilla, A.; Palacios, J. Nano-dimensional CeO 2 nanorods for high $\mathrm{Ni}$ loading catalysts: $\mathrm{H}_{2}$ production by autothermal steam reforming of methanol reaction. Phys. Chem. Chem. Phys. 2013, 15, 12702-12708. [CrossRef]

123. Roh, H.-S.; Jun, K.-W.; Dong, W.-S.; Chang, J.-S.; Park, S.-E.; Joe, Y.-I. Highly active and stable Ni/Ce-ZrO 2 catalyst for $\mathrm{H}_{2}$ production from methane. J. Mol. Catal. A Chem. 2002, 181, 137-142. [CrossRef]

124. Lu, Y.; Xue, J.; Yu, C.; Liu, Y.; Shen, S. Mechanistic investigations on the partial oxidation of methane to synthesis gas over a nickel-on-alumina catalyst. Appl. Catal. A Gen. 1998, 174, 121-128. [CrossRef]

125. Santos, A.C.S.F.; Damyanova, S.; Teixeira, G.N.R.; Mattos, L.V.; Noronha, F.B.; Passos, F.B.; Bueno, J.M.C. The effect of ceria content on the performance of $\mathrm{Pt} / \mathrm{CeO}_{2} / \mathrm{Al}_{2} \mathrm{O}_{3}$ catalysts in the partial oxidation of methane. Appl. Catal. A Gen. 2005, 290, 123-132. [CrossRef]

126. Cherian, M.; Gupta, R.; Someswara Rao, M.; Deo, G. Effect of Modifiers on the Reactivity of $\mathrm{Cr}_{2} \mathrm{O}_{3} / \mathrm{Al}_{2} \mathrm{O}_{3}$ and $\mathrm{Cr}_{2} \mathrm{O}_{3} / \mathrm{TiO}_{2}$ Catalysts for the Oxidative Dehydrogenation of Propane. Catal. Lett. 2003, 86, 179-189. [CrossRef]

127. Zhu, J.; Peng, X.; Yao, L.; Shen, J.; Tong, D.; Hu, C. The promoting effect of La, Mg, Co and Zn on the activity and stability of $\mathrm{Ni} / \mathrm{SiO}_{2}$ catalyst for $\mathrm{CO}_{2}$ reforming of methane. Int. J. Hydrog. Energy 2011, 36, 7094-7104. [CrossRef]

128. Wang, S.; Lu, G.Q.; Millar, G.J. Carbon Dioxide Reforming of Methane To Produce Synthesis Gas over Metal-Supported Catalysts: State of the Art. Energy Fuels 1996, 10, 896-904. [CrossRef]

129. Men, Y.; Gnaser, H.; Ziegler, C.; Zapf, R.; Hessel, V.; Kolb, G. Characterization of $\mathrm{Cu} / \mathrm{CeO}_{2} / \gamma-\mathrm{Al}_{2} \mathrm{O}_{3}$ Thin Film Catalysts by Thermal Desorption Spectroscopy. Catal. Lett. 2005, 105, 35-40. [CrossRef]

130. Men, Y.; Gnaser, H.; Zapf, R.; Hessel, V.; Ziegler, C. Parallel screening of $\mathrm{Cu} / \mathrm{CeO}_{2} / \gamma-\mathrm{Al}_{2} \mathrm{O}_{3}$ catalysts for steam reforming of methanol in a 10-channel micro-structured reactor. Catal. Commun. 2004, 5, 671-675. [CrossRef]

131. Jeong, H.; Kim, K.I.; Kim, T.H.; Ko, C.H.; Park, H.C.; Song, I.K. Hydrogen production by steam reforming of methanol in a micro-channel reactor coated with $\mathrm{Cu} / \mathrm{ZnO} / \mathrm{ZrO}_{2} / \mathrm{Al}_{2} \mathrm{O}_{3}$ catalyst. J. Power Sources 2006, 159, 1296-1299. [CrossRef] 
132. Sánchez-Sánchez, M.C.; Navarro, R.M.; Fierro, J.L.G. Ethanol steam reforming over Ni/MxOy- $\mathrm{Al}_{2} \mathrm{O}_{3}(\mathrm{M}=\mathrm{Ce}$, $\mathrm{La}, \mathrm{Zr}$ and $\mathrm{Mg}$ ) catalysts: Influence of support on the hydrogen production. Int. J. Hydrog. Energy 2007, 32, 1462-1471. [CrossRef]

133. Dong, W.-S.; Roh, H.-S.; Jun, K.-W.; Park, S.-E.; Oh, Y.-S. Methane reforming over Ni/Ce-ZrO 2 catalysts: Effect of nickel content. Appl. Catal. A Gen. 2002, 226, 63-72. [CrossRef]

134. Roh, H.-S.; Jun, K.-W.; Park, S.-E. Methane-reforming reactions over Ni/Ce- $\mathrm{ZrO}_{2} / \theta-\mathrm{Al}_{2} \mathrm{O}_{3}$ catalysts. Appl. Catal. A Gen. 2003, 251, 275-283. [CrossRef]

135. Mierczynski, P.; Stępińska, N.; Mosinska, M.; Chalupka, K.; Albinska, J.; Maniukiewicz, W.; Rogowski, J.; Nowosielska, M.; Szynkowska, M.I. Hydrogen Production via the Oxy-Steam Reforming of LNG or Methane on Ni Catalysts. Catalysts 2020, 10, 346. [CrossRef]

136. Mierczynski, P.; Mosinska, M.; Stepinska, N.; Chalupka, K.; Nowosielska, M.; Maniukiewicz, W.; Rogowski, J.; Goswami, N.; Vasilev, K.; Szynkowska, M.I. Effect of the support composition on catalytic and physicochemical properties of Ni catalysts in oxy-steam reforming of methane. Catal. Today 2020. [CrossRef]

137. Mosinska, M.; Stepinska, N.; Chalupka, K.; Maniukiewicz, W.; Szynkowska, M.I.; Mierczynski, P. Effect of Ag-Addition on the Catalytic and Physicochemical Properties of $\mathrm{Ni} / \mathrm{ZrO}_{2}$ Catalyst in Oxy-Steam Reforming of CH4 and LNG Processes. Catalysts 2020, 10, 855. [CrossRef]

138. Stawowska, J.; Bartczak, W.M. Computer modeling of metal catalyst deactivation caused by carbon deposit. Przemyst Chem. 2003, 82, 778-782.

139. Dantas, S.C.; Escritori, J.C.; Soares, R.R.; Hori, C.E. Effect of different promoters on $\mathrm{Ni} / \mathrm{CeZrO}_{2}$ catalyst for autothermal reforming and partial oxidation of methane. Chem. Eng. J. 2010, 156, 380-387. [CrossRef]

140. Vita, A.; Cristiano, G.; Italiano, C.; Pino, L.; Specchia, S. Syngas production by methane oxy-steam reforming on $\mathrm{Me} / \mathrm{CeO}_{2}(\mathrm{Me}=\mathrm{Rh}, \mathrm{Pt}, \mathrm{Ni})$ catalyst lined on cordierite monoliths. Appl. Catal. B Environ. 2015, 162, 551-563. [CrossRef]

141. Vita, A.; Cristiano, G.; Italiano, C.; Specchia, S.; Cipitì, F.; Specchia, V. Methane oxy-steam reforming reaction: Performances of $\mathrm{Ru} / \gamma-\mathrm{Al}_{2} \mathrm{O}_{3}$ catalysts loaded on structured cordierite monoliths. Int. J. Hydrog. Energy 2014, 39, 18592-18603. [CrossRef]

142. Yoshida, K.; Begum, N.; Ito, S.-i.; Tomishige, K. Oxidative steam reforming of methane over $\mathrm{Ni} / \alpha-\mathrm{Al}_{2} \mathrm{O}_{3}$ modified with trace noble metals. Appl. Catal. A Gen. 2009, 358, 186-192. [CrossRef]

143. Hosseini, S.M.S.; Hashemipour, H.; Talebizadeh, A. Syngas production through methane oxy-steam reforming over a $\mathrm{Ni} / \mathrm{SiO}_{2}$ nanocatalyst prepared by a modified impregnation method. Micro Nano Lett. 2016, 11, 890-895. [CrossRef]

144. Roh, H.S.; Jun, K.W.; Dong, W.S.; Back, S.C.; Park, S.E. Methane reforming reactions over stable $\mathrm{Ni}^{\prime} \theta-\mathrm{Al}_{2} \mathrm{O}_{3}$ catalysts. J. Ind. Eng. Chem. 2002, 8, 464-471.

145. Jiménez-González, C.; Gil-Calvo, M.; de Rivas, B.; González-Velasco, J.R.; Gutiérrez-Ortiz, J.I.; López-Fonseca, R. Oxidative Steam Reforming and Steam Reforming of Methane, Isooctane, and N-Tetradecane over an Alumina Supported Spinel-Derived Nickel Catalyst. Ind. Eng. Chem. Res. 2016, 55, 3920-3929. [CrossRef]

146. Miletić, N.; Izquierdo, U.; Obregón, I.; Bizkarra, K.; Agirrezabal-Telleria, I.; Bario, L.V.; Arias, P.L. Oxidative steam reforming of methane over nickel catalysts supported on $\mathrm{Al}_{2} \mathrm{O}_{3}-\mathrm{CeO}_{2}-\mathrm{La}_{2} \mathrm{O}_{3}$. Catal. Sci. Technol. 2015, 5, 1704-1715. [CrossRef]

147. Bang, Y.; Han, S.J.; Seo, J.G.; Youn, M.H.; Song, J.H.; Song, I.K. Hydrogen production by steam reforming of liquefied natural gas (LNG) over ordered mesoporous nickel-alumina catalyst. Int. J. Hydrog. Energy 2012, 37, 17967-17977. [CrossRef]

148. Seo, J.G.; Youn, M.H.; Park, S.; Chung, J.S.; Song, I.K. Hydrogen production by steam reforming of liquefied natural gas (LNG) over $\mathrm{Ni} / \mathrm{Al}_{2} \mathrm{O}_{3}-\mathrm{ZrO}_{2}$ xerogel catalysts: Effect of calcination temperature of $\mathrm{Al}_{2} \mathrm{O}_{3}-\mathrm{ZrO}_{2}$ xerogel supports. Int. J. Hydrog. Energy 2009, 34, 3755-3763. [CrossRef]

149. Seo, J.G.; Youn, M.H.; Jung, J.C.; Song, I.K. Hydrogen production by steam reforming of liquefied natural gas (LNG) over mesoporous nickel-alumina aerogel catalyst. Int. J. Hydrog. Energy 2010, 35, 6738-6746. [CrossRef]

(C) 2020 by the authors. Licensee MDPI, Basel, Switzerland. This article is an open access article distributed under the terms and conditions of the Creative Commons Attribution (CC BY) license (http://creativecommons.org/licenses/by/4.0/). 